\title{
Review \\ Regulation of LncRNAs in Melanoma and Their Functional Roles in the Metastatic Process
}

\author{
Marine Melixetian ${ }^{1}$, Pier Giuseppe Pelicci ${ }^{1,2}$ and Luisa Lanfrancone ${ }^{1, *(D)}$ \\ 1 Department of Experimental Oncology, IEO, European Institute of Oncology IRCCS, 20139 Milan, Italy; \\ marine.meliksetyan@ieo.it (M.M.); piergiuseppe.pelicci@ieo.it (P.G.P.) \\ 2 Department of Oncology and Hemato-Oncology, University of Milan, 20122 Milan, Italy \\ * Correspondence: luisa.lanfrancone@ieo.it; Tel.: +39-02-94375011
}

Citation: Melixetian, M.; Pelicci, P.G.; Lanfrancone, L. Regulation of LncRNAs in Melanoma and Their Functional Roles in the Metastatic Process. Cells 2022, 11, 577. https:// doi.org/10.3390/cells11030577

Academic Editor: Yasuhito Ishigaki

Received: 10 January 2022

Accepted: 5 February 2022

Published: 7 February 2022

Publisher's Note: MDPI stays neutral with regard to jurisdictional claims in published maps and institutional affiliations.

Copyright: (c) 2022 by the authors. Licensee MDPI, Basel, Switzerland. This article is an open access article distributed under the terms and conditions of the Creative Commons Attribution (CC BY) license (https:// creativecommons.org/licenses/by/ $4.0 /)$.

\begin{abstract}
Long non-coding RNAs (lncRNAs) are key regulators of numerous intracellular processes leading to tumorigenesis. They are frequently deregulated in cancer, functioning as oncogenes or tumor suppressors. As they act through multiple mechanisms, it is not surprising that they may exert dual functions in the same tumor. In melanoma, a highly invasive and metastatic tumor with the propensity to rapidly develop drug resistance, lncRNAs play different roles in: (i) guiding the phenotype switch and leading to metastasis formation; (ii) predicting the response of melanoma patients to immunotherapy; (iii) triggering adaptive responses to therapy and acquisition of drug resistance phenotypes. In this review we summarize the most recent findings on the lncRNAs involved in melanoma growth and spreading to distant sites, focusing on their role as biomarkers for disease diagnosis and patient prognosis, or targets for novel therapeutic approaches.
\end{abstract}

Keywords: lncRNAs; melanoma; phenotype switch; metastasis; drug targeting; drug resistance

\section{Introduction}

Melanoma is a malignant skin cancer arising from melanocytes, the pigment-forming cells of the skin [1]. It is highly prone to metastatic dissemination and recurrence after treatment, accounting for $73 \%$ of skin-cancer-related deaths in advanced-stage disease [2]. Early diagnosis of melanoma is crucial for patient prognosis and survival, as the 5-year survival rate for localized, early-stage melanoma is $99 \%$, dropping to $65 \%$ for regional disease and only $27 \%$ for metastatic melanomas [3].

Melanoma has the highest mutational burden among cancers, partially attributed to UV-induced DNA damage, and is classified into four genetic subtypes: (i) the B-Raf proto-oncogene serine/threonine-kinase (BRAF) subtype (50\%), defined by BRAF somatic mutations, targeting the V600 amino acid residue (V600E-V600K-V600R) or the K601 residue (K6001I); (ii) the Ras proto-oncogene GTPase (RAS) subtype (25\%), including known damaging amino acid substitutions in all three RAS family members (NRAS, KRAS, and HRAS), more frequently NRAS; (iii) the Neurofibromin 1 (NF1) subtype (15\%), defined by the presence of inactivating mutations in the NF1 negative regulator of the Ras signal transduction pathway; and (iv) Triple Wild-Type Subtype (10\%), described as a heterogeneous subgroup characterized by a lack of hot-spot BRAF, N/K/HRAS, or NF1 mutations. Several COSMIC mutations were found in this subtype, including known drivers of uveal melanoma KIT, GNAQ, and GNA11, as well as CTNNB1 and EZH2 [4].

Melanomagenesis is a complex process involving sequential accumulation of somatic mutations, as reported in other cancers $[5,6]$. Mutations leading to the constitutive activation of the MAPK signaling pathway are considered as the putative sustaining-lesion as their targeting reverts or attenuates the melanoma phenotype [7]. Notably, BRAF or NRAS mutations are frequently mutually exclusive [8-11]. The BRAF V600E mutation is found in up to $80 \%$ of benign naevi, suggesting that it also functions as a cancer-initiating mutation [12]. By contrast, NRAS mutations or BRAF V600K or K601E mutations are 
more commonly associated with intermediate melanoma lesions, which had already accumulated other pathogenic mutations [9]. Progression from early to intermediate lesions and melanoma in situ is usually accompanied by the accumulation of mutations in the telomerase reverse-transcriptase (TERT) promoter and a high mutational burden [5,6,9]. TERT promoter mutations contribute to aberrant telomerase activity contributing to uncontrolled proliferation and immortalization of melanoma cells [6]. The acquisition of the invasive potential correlates instead with the accumulation of mutations affecting a distinct set of genes, including cell-cycle controlling genes (cyclin-dependent kinase-inhibitor 2A, CDKN2A), chromatin-remodeling genes (AT-rich interaction domain ARID1A, ARID1B, ARID2), and genes encoding SWI/SNF subunits. Finally, metastatic melanoma progression is often associated with inactivating mutations in the tumor suppressors phosphataseand-tensin homolog (PTEN) or p53 (TP53) genes [9]). Melanoma metastases are also characterized by a further increase of the tumor mutational burden and copy number alterations, mainly affecting MAPK, phosphoinositide-3-kinase (PI3K), protein-kinase-B (AKT), mammalian-target-of-rapamycin (mTOR), Janus-kinase (JAK), and signal-transducer-andactivator-of-transcription (STAT) pathways [5,9].

Melanoma progression, however, does not always follow a defined evolutionary trajectory of driver gene mutations accumulation and consistently involves non-genetic alterations, including transcriptional and translational reprogramming, due to cellular responses to microenvironmental signals [13]. Indeed, metastasis dissemination involves complex interplays among melanoma cells, host intrinsic factors, and stromal cell populations. Consistently, malignant melanoma is endowed with high levels of intra-tumor heterogeneity and intrinsic plasticity, which enable melanoma cells to switch phenotypes and adapt to the changing and challenging surrounding environment [14].

Transcriptional reprogramming is a critical determinant of the phenotype switch of melanoma cells and is controlled by distinct transcriptional master-regulators, such as MITF, a crucial regulator of the melanoma phenotypic states $[15,16]$. Recent studies using single-cell RNA-sequencing technologies have allowed a detailed description of different phenotype-related transcriptional states [14] and uncovered the importance of phenotype plasticity in the development of metastasis, as well as drug resistance to both targeted-and immune therapy $[17,18]$.

Despite numerous recent advances, melanoma progression and drug resistance still suffer from incomplete knowledge of the underlying mechanisms, representing the leading cause of mortality for this disease. Noncoding RNAs (ncRNAs) are emerging as critical regulators of tumor development in virtually all the analyzed tumor types [19]. Understanding their role in melanoma progression might offer new insights into the process of metastasis formation to better design new therapy approaches.

Noncoding RNAs are transcripts containing short, not evolutionary-conserved open reading frames (ORFs), usually not translated into functional proteins [20]. According to the human GENCODE database, the human genome contains about 16,000 ncRNAtranscribing genes, including snoRNAs, microRNAs, siRNAs, snRNAs, exRNAs, piRNAs, long ncRNAs, and the highly-abundant and functionally defined transfer RNA (tRNA) and ribosomal RNA (rRNA) [21].

Within the ncRNAs, long non-coding RNAs (lncRNAs) are longer than 200 nucleotides, are usually transcribed by RNA polymerase II from specific promoter regions, capped at the $5^{\prime}$ end, spliced, and frequently also polyadenylated at the $3^{\prime}$ end. Compared to proteincoding genes, lncRNA genes lack long ORFs, contain fewer exons ( 2.8 as compared to 11 for protein-coding genes), and are usually expressed at very low levels in a tissuespecific manner. LncRNAs may contain specific sequence motifs to recruit specific nuclear factors that promote their nuclear and/or nucleolar localization [22]. Although, the nuclear localization of lncRNAs is tightly and coordinately regulated at different levels, from transcription to nuclear import/export; however, the mechanisms that control different nuclear localization patterns are still largely unknown. The functional roles of the nuclear lncRNAs were found to require the interaction with RNA-binding proteins (RBPs) [22]. 
A large fraction of the lncRNAs are instead exported to the cytosol, possibly sharing the same processing and export pathways of mRNAs. Upon arrival in the cytoplasm, lncRNAs are either assigned to specific cellular organelles or remain cytosolic and associated with RBPs to determine the function, as it happens in the nucleus [22]. However, nearly half to $70 \%$ of cytoplasmic lncRNAs are found in polysome fractions $[23,24]$. The functions of ribosome-associated RNAs are not fully understood; ribosome binding regulates lncRNAs turnover through nonsense-mediated mRNA decay, and there is an increasing body of evidence that numerous lncRNAs are involved in the regulation of translational initiation and elongation [24,25].

LncRNAs exert important roles in gene expression regulation, acting at multiple levels and in different cellular compartments. The LncRNAs regulate chromatin architecture, recruitment of transcription machinery components, mRNA stability, and, in the cytoplasm, translation and posttranslational processes [26,27]. Nuclear lncRNAs perform these functions by different mechanisms, by acting, for example, as scaffolds that regulate chromatin architecture or recruit chromatin-modifying enzymes (XIST, HOTAIR, DLX6AS [28-31], regulating long-range chromatin interactions [32-34], or regulating transcription directly by forming R-loops or interfering with the Pol II machinery [35-37]. Cytoplasmic lncRNAs are frequently involved in regulating mRNA turnover by different mechanisms [38-41], including association with ribosomes and direct translation-regulation [42-44]. An increasing body of evidence suggests that lncRNAs can also be translated, giving rise to micropeptides encoded by small ORFs [45-48].

An emerging group of lncRNAs are the circular RNAs (circRNAs)-circular RNA molecules that arise from pre-mRNA back-splicing through covalent linking of $5^{\prime}$ and $3^{\prime}$ pre-mRNA termini. About $80 \%$ of circRNAs are exonic cytoplasmic circRNAs that can interact with proteins and other RNAs, acting as microRNA sponges, thus regulating transcription or translation. Also, circRNAs can be translated into micropeptides [49-52].

A growing body of evidence suggests that lncRNAs are aberrantly expressed and deregulated in cancer, functioning as tumor suppressors or oncogenes [19,53]. Given the multiple mechanisms of action known for lncRNAs, it is not surprising that the same lncRNAs may exert dual functions in cancer, acting as either tumor suppressors or oncogenes, depending on the cancer type (H19, BANCR, TINCR, MALAT, XIST) [44,54-59].

This review summarizes the most relevant findings on lncRNAs involved in melanomagenesis and metastatic dissemination, focusing on their role as biomarkers for disease diagnosis and patient prognosis or targets for novel therapeutic approaches.

\section{Oncogenic lncRNAs in Melanoma}

In recent years, several large-scale transcriptomic and genomic studies have identified deregulated lncRNAs in melanomas [60,61]. In a study using a collection of 7256 RNAsequencing libraries from 27 tissues and cancer types, 339 lncRNAs were associated with melanoma [62].

Given the high frequency of BRAF mutations in primary melanomas, several studies aimed at identifying lncRNAs regulated by the mutant BRAF kinase. Analyses of transcriptome remodeling following $\mathrm{BRAF}^{\mathrm{V} 600 \mathrm{E}}$ ectopic-expression in normal melanocytes, for example, Flockhart et al. identified 39 annotated lncRNAs and 70 novel, non-coding transcripts induced by mutant BRAF, including BANCR, a novel lncRNA differentially expressed in primary melanomas as compared to normal melanocytes [61]. BANCR silencing downregulates MAPK signaling inhibits tumor growth and migration by upregulating the chemokine CXCL11. Mechanistically, BANCR acts as a competing endogenous RNA (ceRNA) for miR-204 and is associated with poor prognosis in melanoma $[61,63,64]$. Another BRAF-induced lncRNA is the novel non-coding transcript SPRY4-IT1 (Sprouty RTK Signaling Antagonist 4-Intronic Transcript 1) [65,66], transcribed as an independent transcript from the intronic region of the SPRY4 gene [65]. SPRY4-IT1 is predominantly localized in cytoplasmic polysomes or ribosomal clusters and is overexpressed in melanoma [66]. Its silencing modulates lipid metabolism, impairs cell proliferation and invasion, and induces 
apoptosis in melanoma cells $[66,67]$. Conversely, overexpression of SPRY4-IT1 in normal melanocytes promotes proliferation, multi-nucleation, and anchorage-independent growth. Notably, high levels of SPRY4-IT1 in the plasma of melanoma patients correlate with tumor stage and poor overall survival [68]. Finally, two lncRNAs regulated by the BRAF pathwayMIR31HG and RMEL3- promoted melanoma proliferation and in vivo tumor growth in preclinical models by preventing $\mathrm{p} 16^{\mathrm{INK} 4 \mathrm{~A}}$-dependent cellular senescence and stimulating MAPK and PI3K pathways, respectively [69-71]. Their expression is associated with poor outcomes in melanoma patients [70,72].

Two candidate lncRNAs potentially linked to melanocyte transformation, Taurine upregulated gene 1 (TUG1) and urothelial cancer-associated 1(UCA1), was recently identified as negative regulators of melanogenesis and UVB response in normal melanocytes. TUG1 is overexpressed in melanoma and promotes tumor growth and metastasis formation in model systems by sponging miR-129-5p and miR-29c-3p [73-75]. Likewise, UCA1 overexpression correlates with tumor stage in melanoma patients and promotes proliferation and invasion by regulating the miR-28-5p/HOXB3 and miR-507/FOXM1 axes [76,77]. In normal melanocytes, UCA1 expression is induced by UVB and negatively correlates with MITF expression [78]. Still, until now, no experimental validation has functionally linked TUG1 and UCA1 expression to melanocyte transformation and primary melanoma formation.

The vast majority of melanoma-associated lncRNAs function as miRNA decoys leading to the activation of the main pathways deregulated in cancer: MALAT1, a wellcharacterized lncRNA upregulated in different cancers and functioning as ceRNA, promotes the epithelial-to-mesenchymal transition (EMT) by sponging miR-22 and miR-183 [79,80]; MHENCR activates the PI3K-Akt pathway by sponging miR-425/489 [81]; FOXD3-AS1 activates the MAPK3K2 pathway by sponging miR-325 [82]; KNCQ1OT1 upregulates expression of the MET receptor tyrosine kinase by sponging miR-153 [83]; IncRNA-ATB inhibits the Hippo pathway by upregulating YAP1 expression though miR-5980-5p [84]; NORAD is upregulated in melanoma tissues, where it promotes invasion and metastasis formation through the miR-205-EGLN2 pathway [85]; ZFAS1 stimulates expression of the RAB9A Rab GTPAse family member, by sponging miR-150-5p [86].

Several lncRNAs aberrantly expressed in melanoma regulate gene transcription by acting as scaffolds for chromatin-modifying complexes. In particular, CASC15 and LNMAT1 repress transcription of the programmed cell death 4 PDCD4 and Cell Adhesion Molecule 1 CADM1 tumor suppressor genes, respectively, by recruiting polycomb repressor complexes to target gene-promoters. Transcriptional repression by PDCD4 and CADM1 leads to increased invasion and metastasis formation in melanoma cells [87-90]. The ANRIL lncRNA (antisense non-coding RNA transcribed from the INK4 locus) inhibits transcription of the INK4A and INK4B genes, induces transcriptional reprogramming through the recruitment of polycomb complexes, and possesses well-established oncogenic properties in melanoma [91-93]. The homeobox transcript antisense intergenic RNA (HOTAIR) is one of the 231 ncRNAs associated with the human HOX loci. Its expression in melanomas correlates with tumor stage and its presence in the plasma of melanoma patients with advanced disease [94,95]. HOTAIR is an epigenetic regulator that acts as a scaffold for histone-modification complexes $[28,96]$. In melanoma, HOTAIR also functions as ceRNA for miR-157-3p and activates the c-MET oncogene and the PI3K/AKT/mTOR-signaling pathway, promoting invasion and metastasis [95].

Newly achieved data suggests that lncRNAs control various metabolic pathways in melanoma. The SAMMSON lncRNA regulates mitochondrial metabolism and protein translation by interacting with p32, a master regulator of mitochondrial homeostasis and metabolism. The SAMMSON gene is co-amplified in melanomas together with MITF within the genomic locus 3p13-3p14 and is associated with poor prognosis in melanoma patients. Notably, SAMMSON expression is required for melanoma growth in vivo and in vitro and confers resistance to MAPK inhibitors [97,98]. The lncRNAs H19 and CCAT1, instead, control melanoma cell invasion in vitro and tumor growth in vivo by regulating glucose metabolism [99-101]. The lncRNA LINC00518 directly regulates levels of the 
hypoxia-inducible factor HIF $1 \alpha$ and glucose consumption in melanoma cells and promotes melanoma invasion, tumor growth, and radio-resistance in mice xenografts [102]. Importantly, these lncRNAs display low expression in normal tissues and, for this reason, might represent promising drug targets and biomarkers in melanoma.

Natural antisense transcripts (NAT) constitute one of the most important lncRNA classes aberrantly expressed in melanoma. Oncogenic antisense lncRNA LHFPL3-AS1 is overexpressed in melanoma, particularly in the ALDH1-positive subpopulation of the MDA-MB-435 melanoma cell line, enriched of bona fide melanoma initiating cells [103]. LHFPL3-AS1 upregulates the miR-181a-5p/BCL2 and miR585/STAT3 feedback loops, which are required for melanoma migration, invasion, and growth in vitro and in vivo and is an unfavorable prognostic marker in melanoma patients [104,105]. Another natural antisense transcript, the lncRNA TTN-AS1, regulates in cis the activity of the Titin gene promoter and stimulates melanoma cell migration, invasion, and tumor formation in vivo [106]. The already mentioned OIP5-AS1 is a NAT transcribed from the promoter of the cancer-testis specific gene OIP5, is overexpressed in melanomas, and drives glutamine catabolism by targeting the miR-217-glutaminase negative feedback loop. Knockdown of OIP5-AS1 impairs in vivo tumor growth in a mouse xenograft model [107].

Circular RNAs are an emerging class of lncRNAs involved in cancer and immune regulation [108]. CircRNAs mainly act as ceRNAs for cancer-associated miRNAs, regulating melanoma growth, invasion, EMT, and immune evasion. The circular RNA circ_0016418 promotes glutamine catabolism by upregulating glutaminase expression $[107,109]$. To date, only circ_0084043, circ_0020710, and circ_0016418 have been demonstrated to function as oncogenes in melanoma in immunocompromised mice [109-114]. Given their low expression in normal tissues, several lncRNAs are regarded as promising melanoma biomarkers (reviewed in [115]) (Figure 1).

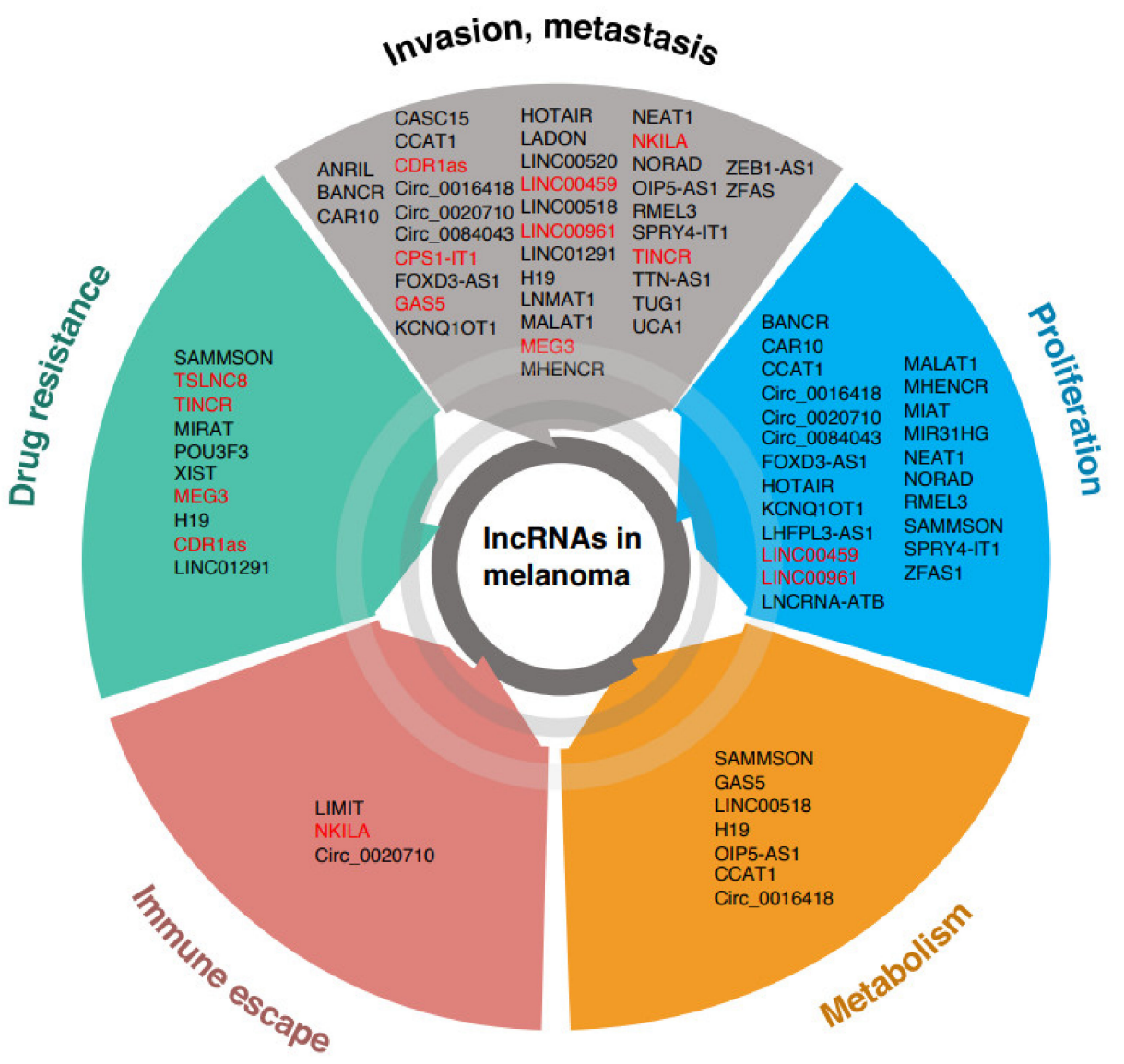

Figure 1. Overview of lncRNAs associated with major hallmarks of melanomagenesis. Melanoma tumor suppressor lncRNAs are highlighted in red. 


\section{Tumor-Suppressor IncRNAs in Melanoma}

Even though most lncRNAs are upregulated in melanoma compared to normal tissues, some are downregulated in primary and metastatic melanomas, suggesting a role in tumor suppression. The MITF and SOX10 transcription factors act as important regulators of melanoma phenotypic-state transition and control invasive and metastatic features of melanoma [116]. Thus, the lncRNAs targeted by the MITF-SOX10 network can also function as potential tumor suppressors and inhibitors of metastasis formation, yet their function is still largely uncharacterized. Coe et al. identified 245 lncRNAs targeted by MITF-SOX10. Among these, the authors identified and characterized a novel lncRNA and DIRC3, expressed in melanocytes and silenced in proliferating MITF-SOX10 highexpressing melanomas [117]. DIRC3 acts in cis as an epigenetic regulator of IGFBP5 gene expression and inhibits invasion and migration of melanoma cells.

The NFkB-interacting lncRNA (NKILA) is a well-characterized tumor suppressor in various cancer types [118-121]. In melanomas, NKILA inhibits invasion and metastasis dissemination [122] through the inhibition of NFKB signaling. However, Huang et al. identified NKILA expression as a factor contributing to immune evasion in breast cancer PDX models [123], suggesting a further function of NKILA in cancer growth.

A recent study identified the circular cerebellar degeneration related1 antisense transcript (CDR1as) as a novel potential tumor suppressor in melanoma. CDR1as is a splice product of the LINC00632 lncRNA transcript highly expressed in melanocytes and epigenetically silenced by EZH1/PRC2 in primary and metastatic melanomas. CDR1as interacts with the Insulin-like growth factor-binding protein 3 (IGF2BP3); its silencing activates IGF2BP3 and promotes melanoma invasion, resistance to GPX4 inhibitors, and tumor growth in vivo [124].

The lncRNA growth arrest-specific transcript 5 (GAS5) is a tumor suppressor in multiple cancers [125]. In melanoma, GAS5 inhibits growth and invasion by acting as a ceRNA for miR-137 and as a regulator of oxidative stress [126-129].

The IncRNA CPS1 Intronic Transcript 1 (CPS1-IT1) was recently described as a tumor suppressor in different cancer types [130-132]. In melanoma, loss of CPS1-IT1 expression correlates with metastasis formation and clinical stage. The expression of CPS1-IT1 in melanoma cells inhibits cell migration, invasion, EMT, and angiogenesis by repressing the expression of CYR61, a SMARCA4-dependent inducer of angiogenesis [133]. Other lncRNAs that inhibit melanoma growth and metastasis dissemination include LINC00961, LINC00459, and MEG3, all acting as miRNA decoys [134-138].

We identified TINCR lncRNA as a suppressor of melanoma invasion and metastasis formation [44]. TINCR expression prevents translational reprogramming, activation of ATF4, and stress response in melanoma. We showed that TINCR is mildly expressed in melanocytes and upregulated in primary melanomas, where it functions as a barrier to the invasive phenotype switch. Consistently, metastatic melanomas display very low levels of TINCR RNA. Restoration of high-level expression of TINCR in metastatic melanomas reverts the invasive phenotype, thus demonstrating the direct involvement of TINCR in the metastatic process [44]. Importantly, TINCR was described as an oncogene in other cancers, acting as ceRNA for various miRNAs. These data suggest that TINCR regulates several cancer pathways through different mechanisms and that the contribution of TINCR to cancer development is cell- and tissue- context-dependent (Figure 1).

\section{LncRNAs in the Phenotype Switching and Metastasis Formation Process}

Melanoma cells display high inter- and intra-tumor heterogeneity and phenotype plasticity, allowing them to adapt to hostile tumor microenvironmental (TME) conditions. The latter process, called "phenotype switch", is a reversible process of transcriptional and metabolic reprogramming of melanoma cells that can transit from a melanocytic/proliferative to a mesenchymal/highly-invasive phenotype, passing through different intermediate states, and vice versa $[116,139]$. These phenotypic transitions are an important requisite for the dissemination of melanoma and subsequent metastatic niche 
formation [18]. Importantly, while many factors (cytokines, extracellular ligands, small molecule compounds, etc.) were identified as inducers of the invasive cell state, only a few were described as capable of inducing the reverse switch [18].

The phenotype switch is a complex process that involves the coordinated regulation of many different genes and signaling pathways. Recent transcriptomic studies revealed that lncRNAs might be engaged in regulating phenotype switches in melanoma. One is the lncRNA TINCR, whose ectopic expression reduces melanoma cell invasion and expression of invasive markers, driving the transition of invasive cells to intermediate and proliferative cell states [44,140]. TINCR is highly expressed in primary melanomas, is downregulated in metastatic melanomas, and is required to maintain the proliferative cell state. TINCR downregulation inhibits melanoma development in vivo by suppressing the ATF4-CHOP pathway [44] and activating the Hippo pathway [140]. However, the association of TINCR expression with melanoma clinic-pathological features and prognosis is still missing.

Another inducer of the melanoma phenotype switch is the antisense lncRNA ZEB1AS1, a marker of poor prognosis in many cancers [141-143]. ZEB1-AS1 is transcribed from the same promoter of ZEB1 and positively regulates its expression either in cis or at the posttranscriptional level [144-146]. Given the critical role of ZEB1 in EMT transition in various tumor types and phenotype switch and drug resistance in melanoma [147,148], ZEB1-AS1 represents an attractive stratification biomarker and molecular target in melanoma.

A role in melanoma phenotype switch has been hypothesized for several other lncRNAs. CASC15 [88] is an oncogenic lncRNA associated with melanoma progression, which activates the Wnt/ $\beta$-catenin pathway and inhibits expression of PDCD4 [87-89] by recruiting EZH2 and increasing H3K27me3 level at its promoter [87]. However, the effects of CASC15 silencing on the invasive phenotype, expression of mesenchymal markers, and transcriptional reprogramming are still controversial $[87,88]$.

HOTAIR expression is highly increased in metastatic melanomas and also in the lymphocytes surrounding the metastatic cells, suggesting a prominent role of the lncRNA in the invasion process by sponging miR-152-3p to upregulate the tyrosine kinase c-MET, known to be involved in metastasis [94].

The CircRNA_0084043 was reported to be implicated in EMT through direct binding to miR-153-3p, a tumor suppressor capable of regulating EMT by targeting SNAIL (Luan et al., 2018a). Consistently, downregulation of either circRNA_0084043 or miR-153-3p significantly reduces both proliferation and migration of melanoma cells and the levels of SNAIL (Luan et al., 2018a). Furthermore, circ_0084043 expression positively regulates TRIB2 (a scaffold and atypical kinase that signals to canonical MAPKs and regulates the substrates' ubiquitination) by sponging miR-429 Downregulation of TRIB2 upon circ_0084043 knockdown inhibits the Wnt/ $\beta$-catenin signaling, thus suggesting a role of circ_0084043 in the phenotype switch in melanoma [149].

Finally, LADON, the natural antisense transcript of the TGF $\beta$ family member NODAL, promotes the mesenchymal to the amoeboid transition of melanoma cells, a crucial invasion step. Indeed, LADON downregulation allows melanoma cells to maintain a non-invasive phenotype, while its overexpression induces cell motility ad reorganization of the actin cytoskeleton and attenuates cell proliferation. LADON expression is dependent on WNT/bCatenin signaling, whose activation inhibits the expression of the metastasis suppressor NDRG1 [150] (Figure 1).

\section{LncRNAs and Immune Evasion in Melanoma}

Melanoma progression depends not only on the accumulation of genetic alteration and the acquisition of new phenotypic states but also on the interaction of melanoma cells with the immune system [151]. The melanoma niche contains many immune-suppressive cells: regulatory T-cells, myeloid-derived suppressor cells, and tumor-associated macrophages [152]. During melanoma progression, a number of soluble factors released by either tumor or 'mmune-suppressive cells inhibit the capacity of antigen-presenting cells, dendritic cells, or macrophages to process and correctly expose melanoma-associated new antigene, leading 
to impaired T-cell activation and immune evasion [153-155]. Recently, pan-cancer genomewide studies identified lncRNAs associated gene-expression signatures of the pro-tumor and anti-tumor TME, associated with response to immunotherapy [156-158]. Notably, immune-related lncRNA signatures were shown to be predictive of prognosis, survival, and immunotherapeutic efficacy in breast cancer, lung adenocarcinoma, hepatocellular carcinoma, bladder cancer [159-163], as well in melanoma [157,158,163-168]. Four distinct lncRNAs immune-related signatures predictive of patient prognosis and survival were identified using the cutaneous skin melanoma (SKCM) TCGA dataset, including lncRNAs related to antigen processing and presentation, cytokines, Toll-like and cytokine receptor signaling pathway, and NK cell-mediated immunity $[163,165,167,168]$.

In recent years, advances in understanding the cellular and molecular mechanisms of tumor immune-escape led to the development and approval of many immunotherapies. Immune checkpoint inhibitors (ICI) targeting programmed death-1 (PD-1), its ligand PD-L1, and cytotoxic T lymphocyte-associated antigen 4 (CTLA-4) have revolutionized the treatment of metastatic melanoma, leading to long-term remissions or cure. However, about $50-60 \%$ of patients still show primary resistance to ICI therapy or develop secondary resistance during treatment, and the underlying molecular mechanisms are not fully understood. Among the most characterized cell-autonomous resistance mechanisms is the downregulation of b2-microglobulin and human leukocyte antigens (HLA) expression, leading to tumor evasion from T-cell specific cytotoxicity. Primary ICI-resistance in melanoma is frequently associated with a low mutational burden [169-172].

Yu et al. identified a 4-IncRNA signature (AC002116-2, AP000251-1, TMEM147-AS1, and NKILA) associated with a response to immunotherapy (anti-PD-1, CTLA4 and a cytokine tumor vaccine in 71 melanoma patients from the SKCM TCGA dataset) [166]. In another study, Zhou and colleagues using two independent training and validation melanoma-datasets identified a 15-IncRNA signature (AC010904.2, LINC01126, AC012360.1, AC024933.1, AL442128.2, AC022211.4, AC022211.2, AC127496.5, NARF-AS1, AP000919.3, AP005329.2, AC023983.1, AC023983.2, AC139100.1, and AC012615.4) that predicts response to anti-PD-1 monotherapy [164] (Figure 1).

To date, the only lncRNA known to play a direct role in the anti-melanoma immune response is LIMIT, a lncRNA that induces MHC-I expression and tumor immunogenicity. The LIMIT gene is conserved in mice and humans, and its expression correlates with lymphocyte infiltration and expression of interferon response genes in the SKCM TCGA dataset. LIMIT expression is induced by IFN $\gamma$ treatment in melanoma cells and cis-activates the guanylate binding protein (GBP) gene cluster, leading to activation of the MHC-I antigen presentation machinery through the heat shock factor 1 (HSF1). Li and colleagues showed that increased LIMIT expression in melanoma patients and mouse transplanted melanomas correlates with MHC-I response, antitumor immunity, and enhanced efficiency of antiPD-1 therapy. This is the first discovery of an immunogenic lncRNA in cancer, whose therapeutic targeting can represent a useful approach to increase the efficacy of cancer immunotherapy [173].

Circular RNAs are an emerging class of RNAs involved in the regulation of immune response [174]. A recently described circRNA, circ_0020710, deriving from CD151 mRNA encoding an oncogenic transmembrane protein, promotes melanoma progression and contributes to melanoma immune evasion by sponging miR-370-3p and upregulating CXCL12 levels. It was shown that high levels of circ_0020710 correlate with cytotoxic Tlymphocyte exhaustion in melanoma patients and that combined treatment of the CXCL12 inhibitor AMD3100 and anti PD-(L)1 enhance its therapeutic efficacy in mouse xenograft melanoma models [114]. Recent findings support novel functions of cirRNA in natural anti-cancer immunity. The innate immune system in mammals can distinguish between native vs. exogenous circRNA. N6-methyladenosine (m6A) methylation is critical for discrimination, which is the most frequent and abundant transcriptional modification in eukaryotic RNAs. While m6A-modified circRNAs inhibit immune response and are recognized as self cirRNAs, foreign m6A-unmodified circRNAs are potent activators of 
the anti-tumor immune response, opening the possibility of using circRNAs in cancer immunotherapy [175]. Still, the role of m6A modification in anti-tumor immune response remains controversial. It was recently described that circNDUFB2 triggers an antitumor immune response in non-small lung cancer (NSCLC) mouse model independently of m6A modification [176].

Increasing evidence suggests that small ORFs in the lncRNAs are translated into small peptides, representing a source of cancer-associated antigens (neoantigens) in different cancer types [52,177]. Increased neoantigen load in cancer cells is reported to increase the efficiency of immune-checkpoint inhibitor (ICI) therapy [178,179]. Qi et al. performed comprehensive proteogenomic profiling of HLA class 1-presented immunopeptides in melanomas with a high tumor mutation burden. The authors identified 44 lncRNA-derived peptides presented by HLA class I. These data suggest that deregulation of lncRNA expression in melanoma can impact neoantigen load and predict the response of melanoma patients to immunotherapy (Figure 1).

\section{LncRNAs and Drug Resistance in Melanoma}

In recent years, the development of targeted small-molecule inhibitors has revolutionized melanoma standard-of-care and improved patient overall survival. The most frequently targeted cellular pathway in melanoma is the MAPK/ERK pathway, activated by the RAS and BRAF mutations in most melanoma patients. Both are gain-of-function mutations, driving MAPK pathway activation via MEK1/2 and ERK1/2 [180-182]. The discovery of the oncogenic BRAF mutation and the activation of the MAPK pathway signaling led to the development of successful combination therapies, targeting BRAF with either vemurafenib [183,184] or dabrafenib [185] and MEK kinase with trametinib [186]. Although clinical trials with MEK inhibitors have shown less impressive responses than BRAF inhibitors in monotherapy, combination therapies have significantly improved initial results showing unprecedented clinical responses [187].

However, intrinsic (5\%) and acquired (50\%) resistance to targeted therapy is still the major challenge for melanoma patients. Two major mechanisms underlie the onset of therapy resistance. The first is the genetic drug resistance which occurs via a selection of mutations inhibiting the response to selective, targeting inhibitors mainly through the acquisition of mutations in the drug-binding domain of targeted kinases and in the pathway downstream effectors [188]. The second mechanism relies on the intrinsic phenotypic plasticity and intratumor heterogeneity of melanoma cells which trigger adaptive responses to therapy and acquisition of drug resistance phenotypes [18]. The best-characterized mechanism is the phenotype switch from MITF ${ }^{\text {high/ }} \mathrm{AXL}^{\text {low }}$ drug-sensitive to MITF ${ }^{\text {low } / A X L}{ }^{\text {high }}$ drug-resistant melanoma cells induced by inhibitors of the MAPK pathway $[18,189,190]$. Unfortunately, most patients develop secondary resistance and eventually relapse despite the initial responses. Emerging evidence suggests that the same lncRNAs involved in the phenotype switch in melanoma are also involved in the acquired resistance to MAPK pathway inhibitors.

The lncRNA TSLNC8 is downregulated in melanoma patient samples with acquired resistance to vemurafenib and vemurafenib-resistant melanoma cell lines. Mechanistically, TSLNC8 binds to and regulates the subcellular localization of the catalytic subunit of protein phosphatase $1 \alpha(\mathrm{PP} 1 \alpha)$. Knockdown of TSLNC8 results in the cytoplasmic accumulation of PP1 $\alpha$ and re-activation of the MAPK signaling [191].

The lncRNA SAMMSON, which controls mitochondrial metabolism and functions as an oncogene in melanoma, is upregulated following inhibition of the ERK signaling in mutant BRAF melanoma cells, and its depletion sensitizes melanoma cells to BRAF inhibitors [97]. Conversely, ectopic expression of SAMMSON confers resistance of melanoma cells to vemurafenib [98].

The long intergenic lncRNA MIRAT is upregulated following prolonged MAPK inhibition in NRAS mutant melanomas and modulates MAPK signaling by binding to the MEK scaffold protein IQGAP1 [192]. The lncRNA POU3F3 promotes resistance of melanoma 
cells to the alkylating agent dacarbazine, upregulating the DNA-methyltransferase MGMT levels by sponging miR-650 [193]. Finally, the lncRNAs XIST, H19, MEG3, and LINC01291 were shown to confer resistance of melanoma cells to platinum compounds by regulating miR-21/PI3KR1 miR-18/IGF1, miR-499-5p/CYLD, and miR-625-5p/IGF-1R axis, respectively $[136,194-196]$.

Recently, we discovered that the lncRNA TINCR plays a novel role in drug resistance in melanoma patients. TINCR knockdown leads to ATF4 activation, downregulation of MITF, and acquisition of an invasive phenotype, accompanied by increased resistance to vemurafenib and trametinib. Importantly, overexpression of TINCR in melanoma patientderived xenografts partially reduced melanoma cell invasiveness and sensitized cells to the MEK1/2 inhibitor trametinib [44] (Figure 1).

\section{LncRNAs as Biomarkers in Melanoma}

LncRNAs can be secreted by cells and detected in different body fluids, such as blood, plasma/serum, or urine [197]. They originate from apoptotic and necrotic cells or are actively secreted by living cells through extracellular vesicles. Secreted vesicles protect lncRNAs from degradation by RNAses and are therefore good candidates as stable markers for diagnosis or prognostic stratification [198].

Several circulating lncRNAs have been described in melanoma patients. lncRNA HOTAIR was found in the plasma of patients with advanced melanoma, while HOTAIR expression in melanoma tumors strongly correlates with tumor stage [94]. The lncRNA LINC01638 is significantly upregulated in the plasma of melanoma patients and predicts local recurrence [199]. Similarly, SPRY4-IT1 expression is increased in the plasma of melanoma patients compared to healthy individuals, and its expression highly correlates with tumor site and stage [68]. The plasmacytoma variant translocation 1 (PVT1) lncRNA was also detected at elevated levels in the serum of melanoma patients, and its expression correlates with tumor stage and is a marker of postoperative disease dynamics [200] Kolenda and colleagues identified a 17-lncRNAs signature in the plasma of melanoma patients that distinguishes healthy individuals and melanoma patients. Three of these lncRNAs-IGF2AS, MEG3, ZEB2-AS1 - were identified as independent prognostic factors in $B R A F$-mutant advanced melanoma patient sera treated with vemurafenib [201].

\section{LncRNAs as Drug Targets}

Given their function in cancer progression, lncRNAs represent attractive targets for developing new drugs. Different RNA-based approaches were employed to create lncRNAtargeting drugs, such as posttranscriptional downregulation using antisense oligonucleotides (ASOs), small interfering RNAs (siRNAs), small hairpin (shRNAs), therapeutic circular RNAs, and CRISPR-Cas9 gene editing approaches [202-204]. The last generation of ASOs includes phosphorothioate oligonucleotides and locked nucleic acids (LNA) modifications, chimeric RNA-DNA-RNA ASOS (GAPmers) bearing LNA, and S-constrained ethyl modifications that have demonstrated improved potency and in vivo stability $[97,205]$.

A new approach to lncRNA targeting involves the steric inhibition of lncRNA interactions with nucleic acids and proteins or targeting a small molecule of lncRNA elements responsible for secondary and tertiary RNA structure formation. These small molecules can potentially destabilize lncRNA molecules or inhibit their biological functions by inhibiting their molecular interactions. The small molecule NP-C86 has been shown to disrupt the interaction of the tumor suppressor GAS5 lncRNA with UPF1, a protein involved in nonsense-mediated decay, leading to upregulation of GAS5 RNA [206]. Two other studies identified small molecules targeting the $3^{\prime}$ triple-helix element of MALAT1 lncRNA, leading to a significant reduction of its expression $[207,208]$

Natural Antisense RNAs have been used to cis-regulate neighboring genes, as shown for the CDKN2B and CDKN1A loci by the lncRNA ANRIL [91] and LincRNA-p21 [209], respectively. The long intergenic noncoding RNA p21 has also been described as an inducer of the transcriptional activity of wild-type p53 [210]. Currently, several chemically 
modified single-stranded ASOS, named antagoNATs, are under preclinical and clinical development [211,212].

In addition, recent advances in RNA-based therapeutics approaches and applications open novel possibilities for using lncRNAs as drug themselves [203,204]. The delivery system is key to properly exploiting the envisioned drug role for lncRNAs. To be satisfactory, lncRNAs should be conveyed with high stability, specificity, cell permeability, and low immunogenicity. The most frequently used carriers are viral vectors, both lentiviral and adenoviral vectors, which can rapidly infect dividing and non-dividing cells and have very long-expression time. However, the safety of viral vectors in systemic drug administration has been a matter of discussion, and these vectors have been recently replaced by non-viral vectors, such as liposomes, lipid nanoparticles (NPs), and exosomes [203].

Liposomes are an ideal type of nanoparticles for drug and DNA/RNA delivery, as they show reduced toxicity and immunogenicity, and encapsulation improves drug stability. Several liposome-encapsulated lncRNAs are used in preclinical experiments in vitro and in vivo [213-215].

Lipid NPs are similar to liposomes, but they are more suitable for encapsulating lncRNAs. They proved to inhibit tumor growth in preclinical animal trials, with no serious side effects [216]. Recently, ASO-gold-TAT NPs were used to target the nuclear IncRNA MALAT1 in a mouse model of xenotransplanted lung cancer, showing the efficient suppression of metastasis dissemination and increased overall survival [217].

Exosomes are membrane-bound, endogenous vesicles containing lipids, proteins, DNA, mRNAs, miRNAs, and lncRNAs that are naturally secreted by cells [218]. Exosomes are very promising delivery vectors and can be easily engineered to convey lncRNAs. They show lower immunogenicity and higher stability in vivo but an average packaging efficiency compared to liposomes. For this reason, exosomes can now be integrated with liposomes and NPs to improve specificity and deliverability. Liposomes, lipid NPs, and exosomes can be functionalized and delivery optimized by surface modification through genetic engineering or chemical modifications. Vesicles can be coupled with nucleic acid aptamers, antibodies, peptides, protein ligands, polymers, or small molecules [203].

Even if several lncRNAs proved to be promising drug targets or drug themselves in both in vitro and in vivo models, up to now, none of the lncRNA or small molecule targeting lncRNAs have entered clinical trials. Moreover, the initial clinical evaluation of RNA-based drugs in cancer is still controversial: four drugs entered phase II or III clinical trials, but seven were withdrawn because of the off-target effects and lack of efficiency [203]. The delivery, specificity, and immunogenicity of RNA-based drugs remain the major challenges in developing non-coding RNA therapeutics.

\section{Conclusions}

Over the past decade, a growing number of studies have demonstrated the crucial role of lncRNAs as oncogenes and tumor suppressors, highlighting their importance in regulating different cancer hallmarks, thus leading to uncontrolled proliferation, metastasis, and immune escape $[19,219]$.

LncRNAs exert their functions through multiple mechanisms, acting as ceRNAs, regulators of chromatin structure, transcription, mRNA metabolism, stability and splicing, translation, and protein stability. The functions of lncRNAs are cell-context dependent and tissue-specific, and growing evidence suggests that the same lncRNA can act as either tumor suppressor or oncogene depending on cell and tissue contexts [220,221]. These findings established the rationale to investigate lncRNAs as diagnostic/prognostic biomarkers and/or therapeutic targets. The current limit in the knowledge of lncRNAs in melanomagenesis is, however, their poor characterization in vivo, both in terms of their role in tumorigenesis and in physiological function, the latter critical for the design of drug development pipelines. Moreover, the mechanisms of lncRNAs functioning in anti-tumor immune response and tumor microenvironment represents a major hurdle, as they are still 
only partially understood, mostly because of the difficulties in establishing appropriate in vivo models (Figure 2).

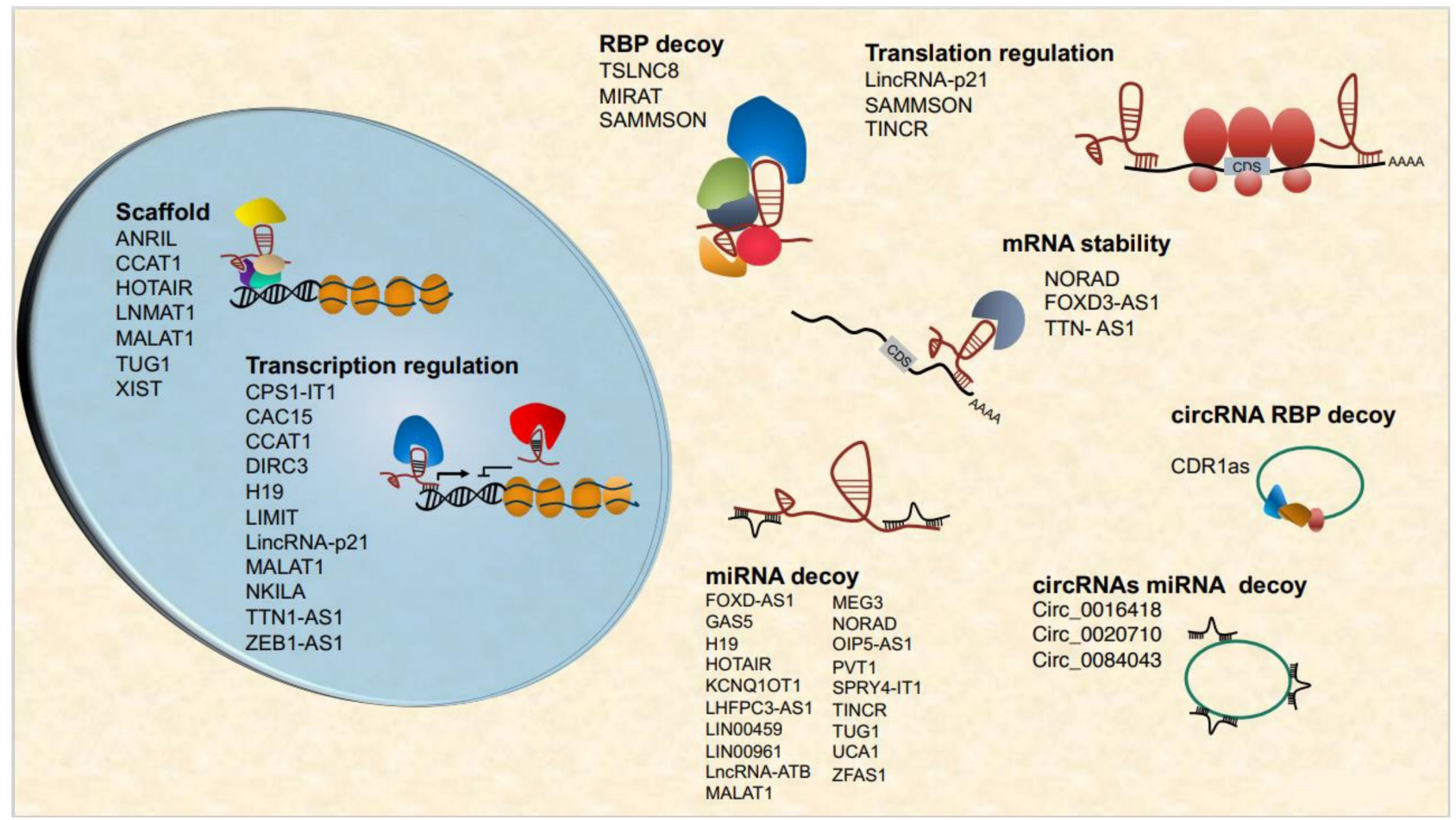

Figure 2. Major functional classes of nuclear and cytoplasmic lncRNAs involved in melanoma progression.

From the translational point of view, lncRNAs are emerging as previously underestimated therapeutic and diagnostic targets. Given the restricted, cancer-specific expression of many oncogenic lncRNAs, their diagnostic testing as cancer biomarkers in liquid biopsies held great promise. Ongoing massive efforts in the field of RNA-therapeutics will allow the exploitation of the usage of lncRNA as efficient drugs in the modulation of melanoma growth and its interaction with the immune system.

Author Contributions: All authors have contributed to the writing and editing. All authors have read and agreed to the published version of the manuscript.

Funding: This research was partially funded by the AIRC grant IG 2017 Id 20508 to L.L., and the Italian Ministry of Health with Ricerca Corrente and 5x1000 funds.

Institutional Review Board Statement: Not applicable.

Informed Consent Statement: Not applicable.

Data Availability Statement: Not applicable.

Conflicts of Interest: The authors declare no conflict of interest.

\section{References}

1. Palmieri, G.; Colombino, M.; Casula, M.; Manca, A.; Mandala, M.; Cossu, A.; Italian Melanoma, I. Molecular Pathways in Melanomagenesis: What We Learned from Next-Generation Sequencing Approaches. Curr. Oncol. Rep. 2018, 20, 86. [CrossRef] [PubMed]

2. Carr, S.; Smith, C.; Wernberg, J. Epidemiology and Risk Factors of Melanoma. Surg. Clin. North. Am. 2020, 100, 1-12. [CrossRef] [PubMed]

3. Matthews, N.H.; Li, W.Q.; Qureshi, A.A.; Weinstock, M.A.; Cho, E. Epidemiology of Melanoma. In Cutaneous Melanoma: Etiology and Therapy; Ward, W.H., Farma, J.M., Eds.; Exon Publications: Brisbane, Australia, 2017. [CrossRef]

4. Cancer Genome Atlas Network. Genomic Classification of Cutaneous Melanoma. Cell 2015, 161, 1681-1696. [CrossRef] [PubMed]

5. Shain, A.H.; Bastian, B.C. From melanocytes to melanomas. Nat. Rev. Cancer 2016, 16, 345-358. [CrossRef] [PubMed] 
6. Chiba, K.; Lorbeer, F.K.; Shain, A.H.; McSwiggen, D.T.; Schruf, E.; Oh, A.; Ryu, J.; Darzacq, X.; Bastian, B.C.; Hockemeyer, D. Mutations in the promoter of the telomerase gene TERT contribute to tumorigenesis by a two-step mechanism. Science 2017, 357, 1416-1420. [CrossRef]

7. Flaherty, K.T.; Hodi, F.S.; Bastian, B.C. Mutation-driven drug development in melanoma. Curr. Opin. Oncol. 2010, 22, 178-183. [CrossRef]

8. Vogelstein, B.; Kinzler, K.W. The Path to Cancer-Three Strikes and You're Out. N. Engl. J. Med. 2015, 373, 1895-1898. [CrossRef]

9. Shain, A.H.; Yeh, I.; Kovalyshyn, I.; Sriharan, A.; Talevich, E.; Gagnon, A.; Dummer, R.; North, J.; Pincus, L.; Ruben, B.; et al. The Genetic Evolution of Melanoma from Precursor Lesions. N. Engl. J. Med. 2015, 373, 1926-1936. [CrossRef]

10. Poynter, J.N.; Elder, J.T.; Fullen, D.R.; Nair, R.P.; Soengas, M.S.; Johnson, T.M.; Redman, B.; Thomas, N.E.; Gruber, S.B. BRAF and NRAS mutations in melanoma and melanocytic nevi. Melanoma Res. 2006, 16, 267-273. [CrossRef]

11. Pollock, P.M.; Harper, U.L.; Hansen, K.S.; Yudt, L.M.; Stark, M.; Robbins, C.M.; Moses, T.Y.; Hostetter, G.; Wagner, U.; Kakareka, J.; et al. High frequency of BRAF mutations in nevi. Nat. Genet. 2003, 33, 19-20. [CrossRef]

12. Michaloglou, C.; Vredeveld, L.C.; Mooi, W.J.; Peeper, D.S. BRAF(E600) in benign and malignant human tumours. Oncogene 2008, 27, 877-895. [CrossRef] [PubMed]

13. Leonardi, G.C.; Falzone, L.; Salemi, R.; Zanghi, A.; Spandidos, D.A.; McCubrey, J.A.; Candido, S.; Libra, M. Cutaneous melanoma: From pathogenesis to therapy (Review). Int. J. Oncol. 2018, 52, 1071-1080. [CrossRef] [PubMed]

14. Arozarena, I.; Wellbrock, C. Phenotype plasticity as enabler of melanoma progression and therapy resistance. Nat. Rev. Cancer 2019, 19, 377-391. [CrossRef] [PubMed]

15. Tirosh, I.; Izar, B.; Prakadan, S.M.; Wadsworth, M.H., 2nd; Treacy, D.; Trombetta, J.J.; Rotem, A.; Rodman, C.; Lian, C.; Murphy, G.; et al. Dissecting the multicellular ecosystem of metastatic melanoma by single-cell RNA-seq. Science 2016, 352, 189-196. [CrossRef]

16. Ennen, M.; Keime, C.; Gambi, G.; Kieny, A.; Coassolo, S.; Thibault-Carpentier, C.; Margerin-Schaller, F.; Davidson, G.; Vagne, C.; Lipsker, D.; et al. MITF-High and MITF-Low Cells and a Novel Subpopulation Expressing Genes of Both Cell States Contribute to Intra- and Intertumoral Heterogeneity of Primary Melanoma. Clin. Cancer Res. 2017, 23, 7097-7107. [CrossRef]

17. Eddy, K.; Shah, R.; Chen, S. Decoding Melanoma Development and Progression: Identification of Therapeutic Vulnerabilities. Front. Oncol. 2020, 10, 626129. [CrossRef]

18. Rambow, F.; Marine, J.C.; Goding, C.R. Melanoma plasticity and phenotypic diversity: Therapeutic barriers and opportunities. Genes Dev. 2019, 33, 1295-1318. [CrossRef]

19. Liu, S.J.; Dang, H.X.; Lim, D.A.; Feng, F.Y.; Maher, C.A. Long noncoding RNAs in cancer metastasis. Nat. Rev. Cancer 2021, 21, 446-460. [CrossRef]

20. Guttman, M.; Rinn, J.L. Modular regulatory principles of large non-coding RNAs. Nature 2012, 482, 339-346. [CrossRef]

21. Seal, R.L.; Chen, L.L.; Griffiths-Jones, S.; Lowe, T.M.; Mathews, M.B.; O’Reilly, D.; Pierce, A.J.; Stadler, P.F.; Ulitsky, I.; Wolin, S.L.; et al. A guide to naming human non-coding RNA genes. EMBO J. 2020, 39, e103777. [CrossRef]

22. Statello, L.; Guo, C.J.; Chen, L.L.; Huarte, M. Gene regulation by long non-coding RNAs and its biological functions. Nat. Rev. Mol. Cell Biol. 2021, 22, 96-118. [CrossRef] [PubMed]

23. Bazin, J.; Baerenfaller, K.; Gosai, S.J.; Gregory, B.D.; Crespi, M.; Bailey-Serres, J. Global analysis of ribosome-associated noncoding RNAs unveils new modes of translational regulation. Proc. Natl. Acad. Sci. USA 2017, 114, E10018-E10027. [CrossRef]

24. Carlevaro-Fita, J.; Rahim, A.; Guigo, R.; Vardy, L.A.; Johnson, R. Cytoplasmic long noncoding RNAs are frequently bound to and degraded at ribosomes in human cells. RNA 2016, 22, 867-882. [CrossRef] [PubMed]

25. Karakas, D.; Ozpolat, B. The Role of LncRNAs in Translation. Noncoding RNA 2021, 7, 16. [CrossRef]

26. Kopp, F.; Mendell, J.T. Functional Classification and Experimental Dissection of Long Noncoding RNAs. Cell 2018, $172,393-407$. [CrossRef] [PubMed]

27. Yao, R.W.; Wang, Y.; Chen, L.L. Cellular functions of long noncoding RNAs. Nat. Cell Biol. 2019, 21, 542-551. [CrossRef]

28. Gupta, R.A.; Shah, N.; Wang, K.C.; Kim, J.; Horlings, H.M.; Wong, D.J.; Tsai, M.C.; Hung, T.; Argani, P.; Rinn, J.L.; et al. Long non-coding RNA HOTAIR reprograms chromatin state to promote cancer metastasis. Nature 2010, 464, 1071-1076. [CrossRef]

29. Chen, C.K.; Blanco, M.; Jackson, C.; Aznauryan, E.; Ollikainen, N.; Surka, C.; Chow, A.; Cerase, A.; McDonel, P.; Guttman, M. Xist recruits the $X$ chromosome to the nuclear lamina to enable chromosome-wide silencing. Science 2016, 354, 468-472. [CrossRef]

30. Rinn, J.L.; Kertesz, M.; Wang, J.K.; Squazzo, S.L.; Xu, X.; Brugmann, S.A.; Goodnough, L.H.; Helms, J.A.; Farnham, P.J.; Segal, E.; et al. Functional demarcation of active and silent chromatin domains in human HOX loci by noncoding RNAs. Cell 2007, 129, 1311-1323. [CrossRef]

31. Berghoff, E.G.; Clark, M.F.; Chen, S.; Cajigas, I.; Leib, D.E.; Kohtz, J.D. Evf2 (Dlx6as) lncRNA regulates ultraconserved enhancer methylation and the differential transcriptional control of adjacent genes. Development 2013, 140, 4407-4416. [CrossRef]

32. Trimarchi, T.; Bilal, E.; Ntziachristos, P.; Fabbri, G.; Dalla-Favera, R.; Tsirigos, A.; Aifantis, I. Genome-wide mapping and characterization of Notch-regulated long noncoding RNAs in acute leukemia. Cell 2014, 158, 593-606. [CrossRef] [PubMed]

33. Xiang, J.F.; Yin, Q.F.; Chen, T.; Zhang, Y.; Zhang, X.O.; Wu, Z.; Zhang, S.; Wang, H.B.; Ge, J.; Lu, X.; et al. Human colorectal cancer-specific CCAT1-L lncRNA regulates long-range chromatin interactions at the MYC locus. Cell Res. 2014, 24, 513-531. [CrossRef] [PubMed] 
34. Ma, W.; Ay, F.; Lee, C.; Gulsoy, G.; Deng, X.; Cook, S.; Hesson, J.; Cavanaugh, C.; Ware, C.B.; Krumm, A.; et al. Fine-scale chromatin interaction maps reveal the cis-regulatory landscape of human lincRNA genes. Nat. Methods 2015, 12, 71-78. [CrossRef] [PubMed]

35. Espinoza, C.A.; Allen, T.A.; Hieb, A.R.; Kugel, J.F.; Goodrich, J.A. B2 RNA binds directly to RNA polymerase II to repress transcript synthesis. Nat. Struct. Mol. Biol. 2004, 11, 822-829. [CrossRef]

36. Mariner, P.D.; Walters, R.D.; Espinoza, C.A.; Drullinger, L.F.; Wagner, S.D.; Kugel, J.F.; Goodrich, J.A. Human Alu RNA is a modular transacting repressor of mRNA transcription during heat shock. Mol. Cell 2008, 29, 499-509. [CrossRef]

37. Boque-Sastre, R.; Soler, M.; Oliveira-Mateos, C.; Portela, A.; Moutinho, C.; Sayols, S.; Villanueva, A.; Esteller, M.; Guil, S. Head-to-head antisense transcription and R-loop formation promotes transcriptional activation. Proc. Natl. Acad. Sci. USA 2015, 112, 5785-5790. [CrossRef]

38. Kleaveland, B.; Shi, C.Y.; Stefano, J.; Bartel, D.P. A Network of Noncoding Regulatory RNAs Acts in the Mammalian Brain. Cell 2018, 174, 350-362.e17. [CrossRef]

39. Gong, C.; Maquat, L.E. IncRNAs transactivate STAU1-mediated mRNA decay by duplexing with 3' UTRs via Alu elements. Nature 2011, 470, 284-288. [CrossRef]

40. Kretz, M.; Siprashvili, Z.; Chu, C.; Webster, D.E.; Zehnder, A.; Qu, K.; Lee, C.S.; Flockhart, R.J.; Groff, A.F.; Chow, J.; et al. Control of somatic tissue differentiation by the long non-coding RNA TINCR. Nature 2013, 493, 231-235. [CrossRef]

41. Lee, S.; Kopp, F.; Chang, T.C.; Sataluri, A.; Chen, B.; Sivakumar, S.; Yu, H.; Xie, Y.; Mendell, J.T. Noncoding RNA NORAD Regulates Genomic Stability by Sequestering PUMILIO Proteins. Cell 2016, 164, 69-80. [CrossRef]

42. Yoon, J.H.; Abdelmohsen, K.; Srikantan, S.; Yang, X.; Martindale, J.L.; De, S.; Huarte, M.; Zhan, M.; Becker, K.G.; Gorospe, M LincRNA-p21 suppresses target mRNA translation. Mol. Cell 2012, 47, 648-655. [CrossRef]

43. Carrieri, C.; Cimatti, L.; Biagioli, M.; Beugnet, A.; Zucchelli, S.; Fedele, S.; Pesce, E.; Ferrer, I.; Collavin, L.; Santoro, C.; et al. Long non-coding antisense RNA controls Uchl1 translation through an embedded SINEB2 repeat. Nature 2012, 491, 454-457. [CrossRef] [PubMed]

44. Melixetian, M.; Bossi, D.; Mihailovich, M.; Punzi, S.; Barozzi, I.; Marocchi, F.; Cuomo, A.; Bonaldi, T.; Testa, G.; Marine, J.C.; et al Long non-coding RNA TINCR suppresses metastatic melanoma dissemination by preventing ATF4 translation. EMBO Rep. 2021, 22, e50852. [CrossRef] [PubMed]

45. Ruiz-Orera, J.; Messeguer, X.; Subirana, J.A.; Alba, M.M. Long non-coding RNAs as a source of new peptides. eLife 2014, 3, e03523. [CrossRef] [PubMed]

46. Anderson, D.M.; Anderson, K.M.; Chang, C.L.; Makarewich, C.A.; Nelson, B.R.; McAnally, J.R.; Kasaragod, P.; Shelton, J.M.; Liou, J.; Bassel-Duby, R.; et al. A micropeptide encoded by a putative long noncoding RNA regulates muscle performance. Cell 2015 160, 595-606. [CrossRef]

47. Van Heesch, S.; Witte, F.; Schneider-Lunitz, V.; Schulz, J.F.; Adami, E.; Faber, A.B.; Kirchner, M.; Maatz, H.; Blachut, S.; Sandmann, C.L.; et al. The Translational Landscape of the Human Heart. Cell 2019, 178, 242-260.e29. [CrossRef]

48. Minati, L.; Firrito, C.; Del Piano, A.; Peretti, A.; Sidoli, S.; Peroni, D.; Belli, R.; Gandolfi, F.; Romanel, A.; Bernabo, P.; et al. One-shot analysis of translated mammalian IncRNAs with AHARIBO. eLife 2021, 10, e59303. [CrossRef] [PubMed]

49. Verduci, L.; Tarcitano, E.; Strano, S.; Yarden, Y.; Blandino, G. CircRNAs: Role in human diseases and potential use as biomarkers. Cell Death Dis. 2021, 12, 468. [CrossRef]

50. Abdelmohsen, K.; Panda, A.C.; Munk, R.; Grammatikakis, I.; Dudekula, D.B.; De, S.; Kim, J.; Noh, J.H.; Kim, K.M.; Martindale, J.L.; et al. Identification of HuR target circular RNAs uncovers suppression of PABPN1 translation by CircPABPN1. RNA Biol. 2017, 14, 361-369. [CrossRef]

51. Hansen, T.B.; Jensen, T.I.; Clausen, B.H.; Bramsen, J.B.; Finsen, B.; Damgaard, C.K.; Kjems, J. Natural RNA circles function as efficient microRNA sponges. Nature 2013, 495, 384-388. [CrossRef]

52. Kong, S.; Tao, M.; Shen, X.; Ju, S. Translatable circRNAs and lncRNAs: Driving mechanisms and functions of their translation products. Cancer Lett. 2020, 483, 59-65. [CrossRef]

53. Nandwani, A.; Rathore, S.; Datta, M. LncRNAs in cancer: Regulatory and therapeutic implications. Cancer Lett. 2021, 501, 162-171. [CrossRef] [PubMed]

54. Hu, X.T.; Xing, W.; Zhao, R.S.; Tan, Y.; Wu, X.F.; Ao, L.Q.; Li, Z.; Yao, M.W.; Yuan, M.; Guo, W.; et al. HDAC2 inhibits EMTmediated cancer metastasis by downregulating the long noncoding RNA H19 in colorectal cancer. J. Exp. Clin. Cancer Res. 2020, 39, 270. [CrossRef] [PubMed]

55. Zhang, Y.; Huang, W.; Yuan, Y.; Li, J.; Wu, J.; Yu, J.; He, Y.; Wei, Z.; Zhang, C. Long non-coding RNA H19 promotes colorectal cancer metastasis via binding to hnRNPA2B1. J. Exp. Clin. Cancer Res. 2020, 39, 141. [CrossRef]

56. Yang, L.; Liu, G. IncRNA BANCR suppresses cell viability and invasion and promotes apoptosis in non-small-cell lung cancer cells in vitro and in vivo. Cancer Manag. Res. 2019, 11, 3565-3574. [CrossRef]

57. Yu, X.; Zheng, H.; Chan, M.T.; Wu, W.K.K. BANCR: A cancer-related long non-coding RNA. Am J. Cancer Res. 2017, 7, 1779-1787.

58. Sharma, U.; Barwal, T.S.; Malhotra, A.; Pant, N.; Vivek; Dey, D.; Gautam, A.; Tuli, H.S.; Vasquez, K.M.; Jain, A. Long non-coding RNA TINCR as potential biomarker and therapeutic target for cancer. Life Sci. 2020, 257, 118035. [CrossRef] [PubMed]

59. Taniue, K.; Akimitsu, N. The Functions and Unique Features of LncRNAs in Cancer Development and Tumorigenesis. Int. J. Mol. Sci. 2021, 22, 632. [CrossRef] 
60. Ortega-Bernal, D.; La Rosa, C.H.G.; Arechaga-Ocampo, E.; Alvarez-Avitia, M.A.; Moreno, N.S.; Rangel-Escareno, C. A metaanalysis of transcriptome datasets characterizes malignant transformation from melanocytes and nevi to melanoma. Oncol. Lett. 2018, 16, 1899-1911. [CrossRef]

61. Flockhart, R.J.; Webster, D.E.; Qu, K.; Mascarenhas, N.; Kovalski, J.; Kretz, M.; Khavari, P.A. BRAFV600E remodels the melanocyte transcriptome and induces BANCR to regulate melanoma cell migration. Genome Res. 2012, 22, 1006-1014. [CrossRef]

62. Iyer, M.K.; Niknafs, Y.S.; Malik, R.; Singhal, U.; Sahu, A.; Hosono, Y.; Barrette, T.R.; Prensner, J.R.; Evans, J.R.; Zhao, S.; et al. The landscape of long noncoding RNAs in the human transcriptome. Nat. Genet. 2015, 47, 199-208. [CrossRef] [PubMed]

63. Li, R.; Zhang, L.; Jia, L.; Duan, Y.; Li, Y.; Bao, L.; Sha, N. Long Non-Coding Rna Bancr Promotes Proliferation in Malignant Melanoma by Regulating Mapk Pathway Activation. PLoS ONE 2014, 9, e100893. [CrossRef] [PubMed]

64. Khaitan, D.; Dinger, M.E.; Mazar, J.; Crawford, J.; Smith, M.A.; Mattick, J.S.; Perera, R.J. The melanoma-upregulated long noncoding RNA SPRY4-IT1 modulates apoptosis and invasion. Cancer Res. 2011, 71, 3852-3862. [CrossRef] [PubMed]

65. Cai, B.; Zheng, Y.; Ma, S.; Xing, Q.; Wang, X.; Yang, B.; Yin, G.; Guan, F. Bancr Contributes to the Growth and Invasion of Melanoma by Functioning as a Competing Endogenous Rna to Upregulate Notch2 Expression by Sponging miR-204. Int. J. Oncol. 2017, 51, 1941-1951. [CrossRef] [PubMed]

66. Mazar, J.; Zhao, W.; Khalil, A.M.; Lee, B.; Shelley, J.; Govindarajan, S.S.; Yamamoto, F.; Ratnam, M.; Aftab, M.N.; Collins, S.; et al. The functional characterization of long noncoding RNA SPRY4-IT1 in human melanoma cells. Oncotarget 2014, 5, 8959-8969. [CrossRef] [PubMed]

67. Li, Z.; Tang, X.; Duan, S. Interference from LncRNA SPRY4-IT1 restrains the proliferation, migration, and invasion of melanoma cells through inactivating MAPK pathway by up-regulating miR-22-3p. Int. J. Clin. Exp. Pathol. 2019, 12, 477-487.

68. Liu, T.; Shen, S.K.; Xiong, J.G.; Xu, Y.; Zhang, H.Q.; Liu, H.J.; Lu, Z.G. Clinical significance of long noncoding RNA SPRY4-IT1 in melanoma patients. FEBS Open Bio 2016, 6, 147-154. [CrossRef] [PubMed]

69. Montes, M.; Nielsen, M.M.; Maglieri, G.; Jacobsen, A.; Hojfeldt, J.; Agrawal-Singh, S.; Hansen, K.; Helin, K.; van de Werken, H.J.G.; Pedersen, J.S.; et al. The lncRNA MIR31HG regulates p16(INK4A) expression to modulate senescence. Nat. Commun. 2015, 6, 6967. [CrossRef]

70. Goedert, L.; Pereira, C.G.; Roszik, J.; Placa, J.R.; Cardoso, C.; Chen, G.; Deng, W.; Yennu-Nanda, V.G.; Silva, W.A., Jr.; Davies, M.A.; et al. RMEL3, a novel BRAFV600E-associated long noncoding RNA, is required for MAPK and PI3K signaling in melanoma. Oncotarget 2016, 7, 36711-36718. [CrossRef]

71. Cardoso, C.; Serafim, R.B.; Kawakami, A.; Goncalves Pereira, C.; Roszik, J.; Valente, V.; Vazquez, V.L.; Fisher, D.E.; Espreafico, E.M. The lncRNA RMEL3 protects immortalized cells from serum withdrawal-induced growth arrest and promotes melanoma cell proliferation and tumor growth. Pigment Cell Melanoma Res. 2019, 32, 303-314. [CrossRef]

72. Xu, H.L.; Tian, F.Z. Clinical significance of lncRNA MIR31HG in melanoma. Eur. Rev. Med. Pharmacol. Sci. 2020, $24,4389-4395$. [CrossRef]

73. Fu, C.; Chen, J.; Lu, J.; Pei, S.; Hu, S.; Jiang, L.; Ding, Y.; Huang, L.; Xiang, H.; Huang, J.; et al. Downregulation of TUG1 promotes melanogenesis and UVB-induced melanogenesis. Exp. Dermatol. 2019, 28, 730-733. [CrossRef] [PubMed]

74. Long, J.; Menggen, Q.; Wuren, Q.; Shi, Q.; Pi, X. Long Noncoding RNA Taurine-Upregulated Gene1 (TUG1) Promotes Tumor Growth and Metastasis Through TUG1/Mir-129-5p/Astrocyte-Elevated Gene-1 (AEG-1) Axis in Malignant Melanoma. Med. Sci. Monit. 2018, 24, 1547-1559. [CrossRef]

75. Wang, Y.; Liu, G.; Ren, L.; Wang, K.; Liu, A. Long non-coding RNA TUG1 recruits miR29c3p from its target gene RGS1 to promote proliferation and metastasis of melanoma cells. Int. J. Oncol. 2019, 54, 1317-1326. [CrossRef] [PubMed]

76. Wei, Y.; Sun, Q.; Zhao, L.; Wu, J.; Chen, X.; Wang, Y.; Zang, W.; Zhao, G. LncRNA UCA1-miR-507-FOXM1 axis is involved in cell proliferation, invasion and G0/G1 cell cycle arrest in melanoma. Med. Oncol. 2016, 33, 88. [CrossRef] [PubMed]

77. Han, C.; Tang, F.; Chen, J.; Xu, D.; Li, X.; Xu, Y.; Wang, S.; Zhou, J. Knockdown of lncRNA-UCA1 inhibits the proliferation and migration of melanoma cells through modulating the miR-28-5p/HOXB3 axis. Exp. Ther. Med. 2019, 17, 4294-4302. [CrossRef]

78. Pei, S.; Chen, J.; Lu, J.; Hu, S.; Jiang, L.; Lei, L.; Ouyang, Y.; Fu, C.; Ding, Y.; Li, S.; et al. The Long Noncoding RNA UCA1 Negatively Regulates Melanogenesis in Melanocytes. J. Investig. Dermatol. 2020, 140, 152-163.e5. [CrossRef]

79. Luan, W.; Li, L.; Shi, Y.; Bu, X.; Xia, Y.; Wang, J.; Djangmah, H.S.; Liu, X.; You, Y.; Xu, B. Long non-coding RNA MALAT1 acts as a competing endogenous RNA to promote malignant melanoma growth and metastasis by sponging miR-22. Oncotarget 2016, 7 , 63901-63912. [CrossRef]

80. Sun, Y.; Cheng, H.; Wang, G.; Yu, G.; Zhang, D.; Wang, Y.; Fan, W.; Yang, W. Deregulation of miR-183 promotes melanoma development via lncRNA MALAT1 regulation and ITGB1 signal activation. Oncotarget 2017, 8, 3509-3518. [CrossRef]

81. Chen, X.; Dong, H.; Liu, S.; Yu, L.; Yan, D.; Yao, X.; Sun, W.; Han, D.; Gao, G. Long noncoding RNA MHENCR promotes melanoma progression via regulating miR-425/489-mediated PI3K-Akt pathway. Am. J. Transl. Res. 2017, 9, 90-102.

82. Chen, X.; Gao, J.; Yu, Y.; Zhao, Z.; Pan, Y. LncRNA FOXD3-AS1 promotes proliferation, invasion and migration of cutaneous malignant melanoma via regulating miR-325/MAP3K2. Biomed. Pharmacother. 2019, 120, 109438. [CrossRef]

83. Guo, B.; Zhang, Q.; Wang, H.; Chang, P.; Tao, K. KCNQ1OT1 promotes melanoma growth and metastasis. Aging 2018, 10, 632-644. [CrossRef] [PubMed]

84. Mou, K.; Liu, B.; Ding, M.; Mu, X.; Han, D.; Zhou, Y.; Wang, L.J. lncRNA-ATB functions as a competing endogenous RNA to promote YAP1 by sponging miR-590-5p in malignant melanoma. Int. J. Oncol. 2018, 53, 1094-1104. [CrossRef] [PubMed] 
85. Chen, Y.; Cao, K.; Li, J.; Wang, A.; Sun, L.; Tang, J.; Xiong, W.; Zhou, X.; Chen, X.; Zhou, J.; et al. Overexpression of long non-coding RNA NORAD promotes invasion and migration in malignant melanoma via regulating the MIR-205-EGLN2 pathway. Cancer Med. 2019, 8, 1744-1754. [CrossRef] [PubMed]

86. Liang, L.; Zhang, Z.; Qin, X.; Gao, Y.; Zhao, P.; Liu, J.; Zeng, W. Long noncoding RNA ZFAS1 promotes tumorigenesis through regulation of miR-150-5p/RAB9A in melanoma. Melanoma Res. 2019, 29, 569-581. [CrossRef] [PubMed]

87. Yin, Y.; Zhao, B.; Li, D.; Yin, G. Long non-coding RNA CASC15 promotes melanoma progression by epigenetically regulating PDCD4. Cell Biosci. 2018, 8, 42. [CrossRef] [PubMed]

88. Lessard, L.; Liu, M.; Marzese, D.M.; Wang, H.; Chong, K.; Kawas, N.; Donovan, N.C.; Kiyohara, E.; Hsu, S.; Nelson, N.; et al. The CASC15 Long Intergenic Noncoding RNA Locus Is Involved in Melanoma Progression and Phenotype Switching. J. Investig. Dermatol. 2015, 135, 2464-2474. [CrossRef]

89. Sheng, L.; Wei, R. Long Non-Coding RNA-CASC15 Promotes Cell Proliferation, Migration, and Invasion by Activating Wnt/betaCatenin Signaling Pathway in Melanoma. Pathobiology 2020, 87, 20-29. [CrossRef]

90. Mou, K.; Zhang, X.; Mu, X.; Ge, R.; Han, D.; Zhou, Y.; Wang, L. LNMAT1 Promotes Invasion-Metastasis Cascade in Malignant Melanoma by Epigenetically Suppressing CADM1 Expression. Front. Oncol. 2019, 9, 569. [CrossRef]

91. Xu, S.; Wang, H.; Pan, H.; Shi, Y.; Li, T.; Ge, S.; Jia, R.; Zhang, H.; Fan, X. ANRIL lncRNA triggers efficient therapeutic efficacy by reprogramming the aberrant INK4-hub in melanoma. Cancer Lett. 2016, 381, 41-48. [CrossRef]

92. Xie, H.; Rachakonda, P.S.; Heidenreich, B.; Nagore, E.; Sucker, A.; Hemminki, K.; Schadendorf, D.; Kumar, R. Mapping of deletion breakpoints at the CDKN2A locus in melanoma: Detection of MTAP-ANRIL fusion transcripts. Oncotarget 2016, 7, 16490-16504. [CrossRef] [PubMed]

93. Yap, K.L.; Li, S.; Munoz-Cabello, A.M.; Raguz, S.; Zeng, L.; Mujtaba, S.; Gil, J.; Walsh, M.J.; Zhou, M.M. Molecular interplay of the noncoding RNA ANRIL and methylated histone H3 lysine 27 by polycomb CBX7 in transcriptional silencing of INK4a. Mol. Cell 2010, 38, 662-674. [CrossRef] [PubMed]

94. Cantile, M.; Scognamiglio, G.; Marra, L.; Aquino, G.; Botti, C.; Falcone, M.R.; Malzone, M.G.; Liguori, G.; Di Bonito, M.; Franco, R.; et al. HOTAIR role in melanoma progression and its identification in the blood of patients with advanced disease. J. Cell Physiol. 2017, 232, 3422-3432. [CrossRef] [PubMed]

95. Luan, W.; Li, R.; Liu, L.; Ni, X.; Shi, Y.; Xia, Y.; Wang, J.; Lu, F.; Xu, B. Long non-coding RNA HOTAIR acts as a competing endogenous RNA to promote malignant melanoma progression by sponging miR-152-3p. Oncotarget 2017, 8, 85401-85414 [CrossRef]

96. Tsai, M.C.; Manor, O.; Wan, Y.; Mosammaparast, N.; Wang, J.K.; Lan, F.; Shi, Y.; Segal, E.; Chang, H.Y. Long noncoding RNA as modular scaffold of histone modification complexes. Science 2010, 329, 689-693. [CrossRef]

97. Leucci, E.; Vendramin, R.; Spinazzi, M.; Laurette, P.; Fiers, M.; Wouters, J.; Radaelli, E.; Eyckerman, S.; Leonelli, C.; Vanderheyden, K.; et al. Melanoma addiction to the long non-coding RNA Sammson. Nature 2016, 531, 518-522. [CrossRef]

98. Han, S.; Yan, Y.; Ren, Y.; Hu, Y.; Wang, Y.; Chen, L.; Zhi, Z.; Zheng, Y.; Shao, Y.; Liu, J. LncRNA SAMMSON Mediates Adaptive Resistance to RAF Inhibition in BRAF-Mutant Melanoma Cells. Cancer Res. 2021, 81, 2918-2929. [CrossRef]

99. Luan, W.; Zhou, Z.; Ni, X.; Xia, Y.; Wang, J.; Yan, Y.; Xu, B. Long non-coding RNA H19 promotes glucose metabolism and cell growth in malignant melanoma via miR-106a-5p/E2F3 axis. J. Cancer Res. Clin. Oncol. 2018, 144, 531-542. [CrossRef]

100. Shi, G.; Li, H.; Gao, F.; Tan, Q. IncRNA H19 predicts poor prognosis in patients with melanoma and regulates cell growth, invasion, migration and epithelial-mesenchymal transition in melanoma cells. Onco Targets Ther. 2018, 11, 3583-3595. [CrossRef]

101. Fan, J.; Kang, X.; Zhao, L.; Zheng, Y.; Yang, J.; Li, D. Long Noncoding RNA CCAT1 Functions as a Competing Endogenous RNA to Upregulate ITGA9 by Sponging MiR-296-3p in Melanoma. Cancer Manag. Res. 2020, 12, 4699-4714. [CrossRef]

102. Liu, Y.; He, D.; Xiao, M.; Zhu, Y.; Zhou, J.; Cao, K. Long noncoding RNA LINC00518 induces radioresistance by regulating glycolysis through an miR-33a-3p/HIF-1alpha negative feedback loop in melanoma. Cell Death Dis. 2021, 12, 245. [CrossRef] [PubMed]

103. Luo, Y.; Dallaglio, K.; Chen, Y.; Robinson, W.A.; Robinson, S.E.; McCarter, M.D.; Wang, J.; Gonzalez, R.; Thompson, D.C.; Norris, D.A.; et al. ALDH1A isozymes are markers of human melanoma stem cells and potential therapeutic targets. Stem Cells 2012, 30, 2100-2113. [CrossRef] [PubMed]

104. Zhang, S.; Wan, H.; Zhang, X. LncRNA LHFPL3-AS1 contributes to tumorigenesis of melanoma stem cells via the miR-181a5p/BCL2 pathway. Cell Death Dis. 2020, 11, 950. [CrossRef]

105. Peng, Q.; Liu, L.; Pei, H.; Zhang, J.; Chen, M.; Zhai, X. A LHFPL3-AS1/miR-580-3p/STAT3 Feedback Loop Promotes the Malignancy in Melanoma via Activation of JAK2/STAT3 Signaling. Mol. Cancer Res. 2020, 18, 1724-1734. [CrossRef] [PubMed]

106. Wang, Y.; Li, D.; Lu, J.; Chen, L.; Zhang, S.; Qi, W.; Li, W.; Xu, H. Long noncoding RNA TTN-AS1 facilitates tumorigenesis and metastasis by maintaining TTN expression in skin cutaneous melanoma. Cell Death Dis. 2020, 11, 664. [CrossRef]

107. Luan, W.; Zhang, X.; Ruan, H.; Wang, J.; Bu, X. Long noncoding RNA OIP5-AS1 acts as a competing endogenous RNA to promote glutamine catabolism and malignant melanoma growth by sponging miR-217. J. Cell Physiol. 2019, 234, 16609. [CrossRef]

108. Chen, L.L. The expanding regulatory mechanisms and cellular functions of circular RNAs. Nat. Rev. Mol. Cell Biol. 2020, 21, 475-490. [CrossRef]

109. Lu, R.; Zhang, X.; Li, X.; Wan, X. Circ_0016418 promotes melanoma development and glutamine catabolism by regulating the miR-605-5p/GLS axis. Int. J. Clin. Exp. Pathol. 2020, 13, 1791-1801. 
110. Jin, C.; Dong, D.; Yang, Z.; Xia, R.; Tao, S.; Piao, M. CircMYC Regulates Glycolysis and Cell Proliferation in Melanoma. Cell Biochem. Biophys. 2020, 78, 77-88. [CrossRef]

111. Chen, J.; Zhou, X.; Yang, J.; Sun, Q.; Liu, Y.; Li, N.; Zhang, Z.; Xu, H. Circ-GLI1 promotes metastasis in melanoma through interacting with p70S6K2 to activate Hedgehog/GLI1 and Wnt/beta-catenin pathways and upregulate Cyr61. Cell Death Dis. 2020, 11, 596. [CrossRef]

112. Luan, W.; Shi, Y.; Zhou, Z.; Xia, Y.; Wang, J. CircRNA_0084043 promote malignant melanoma progression via miR-153-3p/Snail axis. Biochem. Biophys. Res. Commun. 2018, 502, 22-29. [CrossRef] [PubMed]

113. Tang, K.; Zhang, H.; Li, Y.; Sun, Q.; Jin, H. Circular RNA as a Potential Biomarker for Melanoma: A Systematic Review. Front. Cell Dev. Biol. 2021, 9, 638548. [CrossRef] [PubMed]

114. Wei, C.Y.; Zhu, M.X.; Lu, N.H.; Liu, J.Q.; Yang, Y.W.; Zhang, Y.; Shi, Y.D.; Feng, Z.H.; Li, J.X.; Qi, F.Z.; et al. Circular RNA circ_0020710 drives tumor progression and immune evasion by regulating the miR-370-3p/CXCL12 axis in melanoma. Mol. Cancer 2020, 19, 84. [CrossRef]

115. Mecozzi, N.; Vera, O.; Karreth, F.A. Squaring the circle: CircRNAs in melanoma. Oncogene 2021, 40, 5559-5566. [CrossRef] [PubMed]

116. Verfaillie, A.; Imrichova, H.; Atak, Z.K.; Dewaele, M.; Rambow, F.; Hulselmans, G.; Christiaens, V.; Svetlichnyy, D.; Luciani, F.; Van den Mooter, L.; et al. Decoding the regulatory landscape of melanoma reveals TEADS as regulators of the invasive cell state Nat. Commun. 2015, 6, 6683. [CrossRef] [PubMed]

117. Coe, E.A.; Tan, J.Y.; Shapiro, M.; Louphrasitthiphol, P.; Bassett, A.R.; Marques, A.C.; Goding, C.R.; Vance, K.W. The MITF-SOX10 regulated long non-coding RNA DIRC3 is a melanoma tumour suppressor. PLoS Genet. 2019, 15, e1008501. [CrossRef]

118. Jiang, P.; Han, X.; Zheng, Y.; Sui, J.; Bi, W. Long non-coding RNA NKILA serves as a biomarker in the early diagnosis and prognosis of patients with colorectal cancer. Oncol. Lett. 2019, 18, 2109-2117. [CrossRef] [PubMed]

119. Wu, W.; Chen, F.; Cui, X.; Yang, L.; Chen, J.; Zhao, J.; Huang, D.; Liu, J.; Yang, L.; Zeng, J.; et al. LncRNA NKILA suppresses TGF-beta-induced epithelial-mesenchymal transition by blocking NF-kappaB signaling in breast cancer. Int. J. Cancer 2018, 143, 2213-2224. [CrossRef]

120. Liu, B.; Sun, L.; Liu, Q.; Gong, C.; Yao, Y.; Lv, X.; Lin, L.; Yao, H.; Su, F.; Li, D.; et al. A cytoplasmic NF-kappaB interacting long noncoding RNA blocks IkappaB phosphorylation and suppresses breast cancer metastasis. Cancer Cell 2015, 27, 370-381. [CrossRef]

121. Zhang, W.; Guo, Q.; Liu, G.; Zheng, F.; Chen, J.; Huang, D.; Ding, L.; Yang, X.; Song, E.; Xiang, Y.; et al. NKILA represses nasopharyngeal carcinoma carcinogenesis and metastasis by NF-kappaB pathway inhibition. PLoS Genet. 2019, 15, e1008325. [CrossRef]

122. Bian, D.; Gao, C.; Bao, K.; Song, G. The long non-coding RNA NKILA inhibits the invasion-metastasis cascade of malignant melanoma via the regulation of NF-kB. Am. J. Cancer Res. 2017, 7, 28-40.

123. Huang, D.; Chen, J.; Yang, L.; Ouyang, Q.; Li, J.; Lao, L.; Zhao, J.; Liu, J.; Lu, Y.; Xing, Y.; et al. NKILA lncRNA promotes tumor immune evasion by sensitizing T cells to activation-induced cell death. Nat. Immunol 2018, 19, 1112-1125. [CrossRef] [PubMed]

124. Hanniford, D.; Ulloa-Morales, A.; Karz, A.; Berzoti-Coelho, M.G.; Moubarak, R.S.; Sanchez-Sendra, B.; Kloetgen, A.; Davalos, V.; Imig, J.; Wu, P.; et al. Epigenetic Silencing of CDR1as Drives IGF2BP3-Mediated Melanoma Invasion and Metastasis. Cancer Cell 2020, 37, 55-70.e15. [CrossRef] [PubMed]

125. Pickard, M.R.; Williams, G.T. Molecular and Cellular Mechanisms of Action of Tumour Suppressor GAS5 LncRNA. Genes 2015, 6 , 484-499. [CrossRef] [PubMed]

126. Chen, L.; Yang, H.; Xiao, Y.; Tang, X.; Li, Y.; Han, Q.; Fu, J.; Yang, Y.; Zhu, Y. LncRNA GAS5 is a critical regulator of metastasis phenotype of melanoma cells and inhibits tumor growth in vivo. Onco Targets Ther. 2016, 9, 4075-4087. [CrossRef]

127. Bian, D.; Shi, W.; Shao, Y.; Li, P.; Song, G. Long non-coding RNA GAS5 inhibits tumorigenesis via miR-137 in melanoma. Am. J. Transl. Res. 2017, 9, 1509-1520.

128. Chen, L.; Yang, H.; Yi, Z.; Jiang, L.; Li, Y.; Han, Q.; Yang, Y.; Zhang, Q.; Yang, Z.; Kuang, Y.; et al. LncRNA GAS5 regulates redox balance and dysregulates the cell cycle and apoptosis in malignant melanoma cells. J. Cancer Res. Clin. Oncol. 2019, 145, 637-652. [CrossRef]

129. Xu, W.; Yan, Z.; Hu, F.; Wei, W.; Yang, C.; Sun, Z. Long non-coding RNA GAS5 accelerates oxidative stress in melanoma cells by rescuing EZH2-mediated CDKN1C downregulation. Cancer Cell Int. 2020, 20, 116. [CrossRef]

130. Chen, H.; Li, Q.; Liang, J.; Jin, M.; Lu, A. LncRNA CPS1-IT1 serves as anti-oncogenic role in glioma. Biomed. Pharmacother. 2019, 118, 109277. [CrossRef]

131. Zhang, W.; Yuan, W.; Song, J.; Wang, S.; Gu, X. LncRNA CPS1-IT1 suppresses EMT and metastasis of colorectal cancer by inhibiting hypoxia-induced autophagy through inactivation of HIF-1alpha. Biochimie 2018, 144, 21-27. [CrossRef]

132. Wang, Y.S.; Ma, L.N.; Sun, J.X.; Liu, N.; Wang, H. Long non-coding RNA CPS1-IT1 is a positive prognostic factor and inhibits epithelial ovarian cancer tumorigenesis. Eur. Rev. Med. Pharmacol. Sci. 2017, 21, 3169-3175. [PubMed]

133. Zhou, X.; Rao, Y.; Sun, Q.; Liu, Y.; Chen, J.; Bu, W. Long noncoding RNA CPS1-IT1 suppresses melanoma cell metastasis through inhibiting Cyr61 via competitively binding to BRG1. J. Cell Physiol. 2019, 234, 22017-22027. [CrossRef] [PubMed]

134. Mu, X.; Mou, K.H.; Ge, R.; Han, D.; Zhou, Y.; Wang, L.J. Linc00961 inhibits the proliferation and invasion of skin melanoma by targeting the miR367/PTEN axis. Int. J. Oncol. 2019, 55, 708-720. [CrossRef] [PubMed] 
135. Yang, Y.; Xu, W.; Zheng, Z.; Cao, Z. LINC00459 sponging miR-218 to elevate DKK3 inhibits proliferation and invasion in melanoma. Sci. Rep. 2019, 9, 19139. [CrossRef]

136. Long, J.; Pi, X. lncRNA-MEG3 Suppresses the Proliferation and Invasion of Melanoma by Regulating CYLD Expression Mediated by Sponging miR-499-5p. BioMed Res. Int. 2018, 2018, 2086564. [CrossRef]

137. Li, P.; Gao, Y.; Li, J.; Zhou, Y.; Yuan, J.; Guan, H.; Yao, P. LncRNA MEG3 repressed malignant melanoma progression via inactivating Wnt signaling pathway. J. Cell Biochem. 2018, 119, 7498-7505. [CrossRef]

138. Wu, L.; Zhu, L.; Li, Y.; Zheng, Z.; Lin, X.; Yang, C. LncRNA MEG3 promotes melanoma growth, metastasis and formation through modulating miR-21/E-cadherin axis. Cancer Cell Int. 2020, 20, 12. [CrossRef]

139. Wouters, J.; Kalender-Atak, Z.; Minnoye, L.; Spanier, K.I.; De Waegeneer, M.; Bravo Gonzalez-Blas, C.; Mauduit, D.; Davie, K.; Hulselmans, G.; Najem, A.; et al. Robust gene expression programs underlie recurrent cell states and phenotype switching in melanoma. Nat. Cell Biol. 2020, 22, 986-998. [CrossRef]

140. Han, X.; Jia, Y.; Chen, X.; Sun, C.; Sun, J. LncRNA TINCR attenuates the proliferation and invasion, and enhances the apoptosis of cutaneous malignant melanoma cells by regulating the miR4245p/LATS1 axis. Oncol. Rep. 2021, 46, 238. [CrossRef]

141. Siena, A.D.D.; Placa, J.R.; Araujo, L.F.; de Barros, A., II.; Peronni, K.; Molfetta, G.; de Biagi, C.A.O., Jr.; Espreafico, E.M.; Sousa J.F.; Silva, W.A., Jr. Whole transcriptome analysis reveals correlation of long noncoding RNA ZEB1-AS1 with invasive profile in melanoma. Sci. Rep. 2019, 9, 11350. [CrossRef]

142. Wang, Q.; Zhang, R.; Liu, D. Long non-coding RNA ZEB1-AS1 indicates poor prognosis and promotes melanoma progression through targeting miR-1224-5p. Exp. Ther. Med. 2019, 17, 857-862. [CrossRef] [PubMed]

143. Chen, C.; Feng, Y.; Wang, X. LncRNA ZEB1-AS1 expression in cancer prognosis: Review and meta-analysis. Clin. Chim. Acta 2018, 484, 265-271. [CrossRef] [PubMed]

144. Su, W.; Xu, M.; Chen, X.; Chen, N.; Gong, J.; Nie, L.; Li, L.; Li, X.; Zhang, M.; Zhou, Q. Long noncoding RNA ZEB1-AS1 epigenetically regulates the expressions of ZEB1 and downstreAm. molecules in prostate cancer. Mol. Cancer 2017, 16, 142. [CrossRef] [PubMed]

145. Li, T.; Xie, J.; Shen, C.; Cheng, D.; Shi, Y.; Wu, Z.; Deng, X.; Chen, H.; Shen, B.; Peng, C.; et al. Upregulation of long noncoding RNA ZEB1-AS1 promotes tumor metastasis and predicts poor prognosis in hepatocellular carcinoma. Oncogene 2016, 35, 1575-1584. [CrossRef] [PubMed]

146. Luo, N.; Zhang, K.; Li, X.; Hu, Y. ZEB1 induced-upregulation of long noncoding RNA ZEB1-AS1 facilitates the progression of triple negative breast cancer by binding with ELAVL1 to maintain the stability of ZEB1 mRNA. J. Cell Biochem. 2020, 121, 4176-4187. [CrossRef] [PubMed]

147. Richard, G.; Dalle, S.; Monet, M.A.; Ligier, M.; Boespflug, A.; Pommier, R.M.; de la Fouchardiere, A.; Perier-Muzet, M.; Depaepe, L.; Barnault, R.; et al. ZEB1-mediated melanoma cell plasticity enhances resistance to MAPK inhibitors. EMBO Mol. Med. 2016, 8 , 1143-1161. [CrossRef]

148. Bruneel, K.; Verstappe, J.; Vandamme, N.; Berx, G. Intrinsic Balance between ZEB Family Members Is Important for Melanocyte Homeostasis and Melanoma Progression. Cancers 2020, 12, 2248. [CrossRef]

149. Chen, Z.; Chen, J.; Wa, Q.; He, M.; Wang, X.; Zhou, J.; Cen, Y. Knockdown of circ_0084043 suppresses the development of human melanoma cells through miR-429/tribbles homolog 2 axis and Wnt/beta-catenin pathway. Life Sci. 2020, 243, 117323. [CrossRef]

150. Dutriaux, A.; Diazzi, S.; Caburet, S.; Bresesti, C.; Hardouin, S.; Deshayes, F.; Collignon, J.; Flagiello, D. LADON, a natural antisense transcript of NODAL, promotes an invasive behaviour in melanoma cells. bioRxiv 2020. [CrossRef]

151. Cheng, Y.C.; Su, L.Y.; Chen, L.H.; Lu, T.P.; Chuang, E.Y.; Tsai, M.H.; Chuang, L.L.; Lai, L.C. Regulatory Mechanisms and Functional Roles of Hypoxia-Induced Long Non-Coding RNA MTORT1 in Breast Cancer Cells. Front. Oncol. 2021, 11, 663114. [CrossRef]

152. Simiczyjew, A.; Dratkiewicz, E.; Mazurkiewicz, J.; Zietek, M.; Matkowski, R.; Nowak, D. The Influence of Tumor Microenvironment on Immune Escape of Melanoma. Int. I. Mol. Sci. 2020, 21, 8359. [CrossRef] [PubMed]

153. Tucci, M.; Passarelli, A.; Mannavola, F.; Felici, C.; Stucci, L.S.; Cives, M.; Silvestris, F. Immune System Evasion as Hallmark of Melanoma Progression: The Role of Dendritic Cells. Front. Oncol. 2019, 9, 1148. [CrossRef] [PubMed]

154. Escors, D. Tumour immunogenicity, antigen presentation and immunological barriers in cancer immunotherapy. New J. Sci. 2014, 2014, 757534. [CrossRef] [PubMed]

155. Stoitzner, P.; Green, L.K.; Jung, J.Y.; Price, K.M.; Atarea, H.; Kivell, B.; Ronchese, F. Inefficient presentation of tumor-derived antigen by tumor-infiltrating dendritic cells. Cancer Immunol. Immunother. 2008, 57, 1665-1673. [CrossRef]

156. Bagaev, A.; Kotlov, N.; Nomie, K.; Svekolkin, V.; Gafurov, A.; Isaeva, O.; Osokin, N.; Kozlov, I.; Frenkel, F.; Gancharova, O.; et al. Conserved pan-cancer microenvironment subtypes predict response to immunotherapy. Cancer Cell 2021, 39, 845-865.e7. [CrossRef]

157. Li, Y.; Jiang, T.; Zhou, W.; Li, J.; Li, X.; Wang, Q.; Jin, X.; Yin, J.; Chen, L.; Zhang, Y.; et al. Pan-cancer characterization of immune-related lncRNAs identifies potential oncogenic biomarkers. Nat. Commun. 2020, 11, 1000. [CrossRef]

158. Zhang, Z.; Yan, C.; Li, K.; Bao, S.; Li, L.; Chen, L.; Zhao, J.; Sun, J.; Zhou, M. Pan-cancer characterization of lncRNA modifiers of immune microenvironment reveals clinically distinct de novo tumor subtypes. NPJ Genom. Med. 2021, 6, 52. [CrossRef]

159. Li, J.P.; Li, R.; Liu, X.; Huo, C.; Liu, T.T.; Yao, J.; Qu, Y.Q. A Seven Immune-Related lncRNAs Model to Increase the Predicted Value of Lung Adenocarcinoma. Front. Oncol. 2020, 10, 560779. [CrossRef]

160. Ma, W.; Zhao, F.; Yu, X.; Guan, S.; Suo, H.; Tao, Z.; Qiu, Y.; Wu, Y.; Cao, Y.; Jin, F. Immune-related lncRNAs as predictors of survival in breast cancer: A prognostic signature. J. Transl. Med. 2020, 18, 442. [CrossRef] 
161. Zhang, Y.; Zhang, L.; Xu, Y.; Wu, X.; Zhou, Y.; Mo, J. Immune-related long noncoding RNA signature for predicting survival and immune checkpoInt. blockade in hepatocellular carcinoma. J. Cell Physiol. 2020, 235, 9304-9316. [CrossRef]

162. Cao, R.; Yuan, L.; Ma, B.; Wang, G.; Tian, Y. Immune-related long non-coding RNA signature identified prognosis and immunotherapeutic efficiency in bladder cancer (BLCA). Cancer Cell Int. 2020, 20, 276. [CrossRef] [PubMed]

163. Wen, J.; Wang, Y.; Luo, L.; Peng, L.; Chen, C.; Guo, J.; Ge, Y.; Li, W.; Jin, X. Identification and Verification on Prognostic Index of Lower-Grade Glioma Immune-Related LncRNAs. Front. Oncol. 2020, 10, 578809. [CrossRef] [PubMed]

164. Zhou, J.G.; Liang, B.; Liu, J.G.; Jin, S.H.; He, S.S.; Frey, B.; Gu, N.; Fietkau, R.; Hecht, M.; Ma, H.; et al. Identification of 15 lncRNAs Signature for Predicting Survival Benefit of Advanced Melanoma Patients Treated with Anti-PD-1 Monotherapy. Cells 2021, 10, 977. [CrossRef] [PubMed]

165. Wang, Y.; Ba, H.J.; Wen, X.Z.; Zhou, M.; Kucuk, C.; Tamagnone, L.; Wei, L.; You, H. A prognostic model for melanoma patients on the basis of immune-related lncRNAs. Aging 2021, 13, 6554-6564. [CrossRef] [PubMed]

166. Yu, Y.; Zhang, W.; Li, A.; Chen, Y.; Ou, Q.; He, Z.; Zhang, Y.; Liu, R.; Yao, H.; Song, E. Association of Long Noncoding RNA Biomarkers With Clinical Immune Subtype and Prediction of Immunotherapy Response in Patients With Cancer. JAMA Netw. Open 2020, 3, e202149. [CrossRef] [PubMed]

167. Guo, J.H.; Yin, S.S.; Liu, H.; Liu, F.; Gao, F.H. Tumor microenvironment immune-related lncRNA signature for patients with melanoma. Ann. Transl. Med. 2021, 9, 857. [CrossRef]

168. Xiao, B.; Liu, L.; Li, A.; Wang, P.; Xiang, C.; Li, H.; Xiao, T. Identification and validation of immune-related lncRNA prognostic signatures for melanoma. Immun. Inflamm. Dis. 2021, 9, 1044-1054. [CrossRef]

169. Yarchoan, M.; Hopkins, A.; Jaffee, E.M. Tumor Mutational Burden and Response Rate to PD-1 Inhibition. N. Engl. J. Med. 2017, 377, 2500-2501. [CrossRef]

170. Van Allen, E.M.; Miao, D.; Schilling, B.; Shukla, S.A.; Blank, C.; Zimmer, L.; Sucker, A.; Hillen, U.; Foppen, M.H.G.; Goldinger S.M.; et al. Genomic correlates of response to CTLA-4 blockade in metastatic melanoma. Science 2015, 350, 207-211. [CrossRef]

171. Zaretsky, J.M.; Garcia-Diaz, A.; Shin, D.S.; Escuin-Ordinas, H.; Hugo, W.; Hu-Lieskovan, S.; Torrejon, D.Y.; Abril-Rodriguez, G.; Sandoval, S.; Barthly, L.; et al. Mutations Associated with Acquired Resistance to PD-1 Blockade in Melanoma. N. Engl. J. Med. 2016, 375, 819-829. [CrossRef]

172. Hugo, W.; Zaretsky, J.M.; Sun, L.; Song, C.; Moreno, B.H.; Hu-Lieskovan, S.; Berent-Maoz, B.; Pang, J.; Chmielowski, B.; Cherry, G.; et al. Genomic and Transcriptomic Features of Response to Anti-PD-1 Therapy in Metastatic Melanoma. Cell 2016, 165, 35-44. [CrossRef] [PubMed]

173. Li, G.; Kryczek, I.; Nam, J.; Li, X.; Li, S.; Li, J.; Wei, S.; Grove, S.; Vatan, L.; Zhou, J.; et al. LIMIT is an immunogenic lncRNA in cancer immunity and immunotherapy. Nat. Cell Biol. 2021, 23, 526-537. [CrossRef] [PubMed]

174. Zhou, Z.; Sun, B.; Huang, S.; Zhao, L. Roles of circular RNAs in immune regulation and autoimmune diseases. Cell Death Dis. 2019, 10, 503. [CrossRef] [PubMed]

175. Chen, Y.G.; Chen, R.; Ahmad, S.; Verma, R.; Kasturi, S.P.; Amaya, L.; Broughton, J.P.; Kim, J.; Cadena, C.; Pulendran, B.; et al. N6-Methyladenosine Modification Controls Circular RNA Immunity. Mol. Cell 2019, 76, 96-109.e9. [CrossRef]

176. Li, B.; Zhu, L.; Lu, C.; Wang, C.; Wang, H.; Jin, H.; Ma, X.; Cheng, Z.; Yu, C.; Wang, S.; et al. circNDUFB2 inhibits non-small cell lung cancer progression via destabilizing IGF2BPs and activating anti-tumor immunity. Nat. Commun. 2021, 12, 295. [CrossRef]

177. Lu, S.; Zhang, J.; Lian, X.; Sun, L.; Meng, K.; Chen, Y.; Sun, Z.; Yin, X.; Li, Y.; Zhao, J.; et al. A hidden human proteome encoded by 'non-coding' genes. Nucleic Acids Res. 2019, 47, 8111-8125. [CrossRef]

178. McGranahan, N.; Furness, A.J.; Rosenthal, R.; Ramskov, S.; Lyngaa, R.; Saini, S.K.; Jamal-Hanjani, M.; Wilson, G.A.; Birkbak, N.J.; Hiley, C.T.; et al. Clonal neoantigens elicit T cell immunoreactivity and sensitivity to immune checkpoInt. blockade. Science 2016, 351, 1463-1469. [CrossRef]

179. Keenan, T.E.; Burke, K.P.; Van Allen, E.M. Genomic correlates of response to immune checkpoInt. blockade. Nat. Med. 2019, 25, 389-402. [CrossRef]

180. Davies, H.; Bignell, G.R.; Cox, C.; Stephens, P.; Edkins, S.; Clegg, S.; Teague, J.; Woffendin, H.; Garnett, M.J.; Bottomley, W.; et al. Mutations of the BRAF gene in human cancer. Nature 2002, 417, 949-954. [CrossRef]

181. Wan, P.T.; Garnett, M.J.; Roe, S.M.; Lee, S.; Niculescu-Duvaz, D.; Good, V.M.; Jones, C.M.; Marshall, C.J.; Springer, C.J.; Barford, D.; et al. Mechanism of activation of the RAF-ERK signaling pathway by oncogenic mutations of B-RAF. Cell 2004, 116, 855-867. [CrossRef]

182. Helias-Rodzewicz, Z.; Funck-Brentano, E.; Terrones, N.; Beauchet, A.; Zimmermann, U.; Marin, C.; Saiag, P.; Emile, J.F. Variation of mutant allele frequency in NRAS Q61 mutated melanomas. BMC Dermatol. 2017, 17, 9. [CrossRef] [PubMed]

183. Chapman, P.B.; Hauschild, A.; Robert, C.; Haanen, J.B.; Ascierto, P.; Larkin, J.; Dummer, R.; Garbe, C.; Testori, A.; Maio, M.; et al Improved survival with vemurafenib in melanoma with BRAF V600E mutation. N. Engl. J. Med. 2011, 364, 2507-2516. [CrossRef] [PubMed]

184. Sosman, J.A.; Kim, K.B.; Schuchter, L.; Gonzalez, R.; Pavlick, A.C.; Weber, J.S.; McArthur, G.A.; Hutson, T.E.; Moschos, S.J.; Flaherty, K.T.; et al. Survival in BRAF V600-mutant advanced melanoma treated with vemurafenib. N. Engl. J. Med. 2012, 366, 707-714. [CrossRef] [PubMed]

185. Hauschild, A.; Grob, J.J.; Demidov, L.V.; Jouary, T.; Gutzmer, R.; Millward, M.; Rutkowski, P.; Blank, C.U.; Miller, W.H., Jr.; Kaempgen, E.; et al. Dabrafenib in BRAF-mutated metastatic melanoma: A multicentre, open-label, phase 3 randomised controlled trial. Lancet 2012, 380, 358-365. [CrossRef] 
186. Flaherty, K.T.; Robert, C.; Hersey, P.; Nathan, P.; Garbe, C.; Milhem, M.; Demidov, L.V.; Hassel, J.C.; Rutkowski, P.; Mohr, P.; et al. Improved survival with MEK inhibition in BRAF-mutated melanoma. N. Engl. J. Med. 2012, 367, 107-114. [CrossRef]

187. Long, G.V.; Hauschild, A.; Santinami, M.; Atkinson, V.; Mandala, M.; Chiarion-Sileni, V.; Larkin, J.; Nyakas, M.; Dutriaux, C.; Haydon, A.; et al. Adjuvant Dabrafenib plus Trametinib in Stage III BRAF-Mutated Melanoma. N. Engl. J. Med. 2017, 377, 1813-1823. [CrossRef]

188. Kozar, I.; Margue, C.; Rothengatter, S.; Haan, C.; Kreis, S. Many ways to resistance: How melanoma cells evade targeted therapies. Biochim. Biophys. Acta Rev. Cancer 2019, 1871, 313-322. [CrossRef]

189. Hugo, W.; Shi, H.; Sun, L.; Piva, M.; Song, C.; Kong, X.; Moriceau, G.; Hong, A.; Dahlman, K.B.; Johnson, D.B.; et al. Non-Genomic and Immune Evolution of Melanoma Acquiring Mapki Resistance. Cell 2015, 162, 1271-1285. [CrossRef]

190. Muller, J.; Krijgsman, O.; Tsoi, J.; Robert, L.; Hugo, W.; Song, C.; Kong, X.; Possik, P.A.; Cornelissen-Steijger, P.D.; Foppen, M.H.G.; et al. Low Mitf/Axl Ratio Predicts Early Resistance to Multiple Targeted Drugs in Melanoma. Nat. Commun. 2014, 5 , 5712. [CrossRef]

191. Han, Y.; Fang, J.; Xiao, Z.; Deng, J.; Zhang, M.; Gu, L. Downregulation of lncRNA TSLNC8 promotes melanoma resistance to BRAF inhibitor PLX4720 through binding with PP1alpha to re-activate MAPK signaling. J. Cancer Res. Clin. Oncol. 2021, 147, 767-777. [CrossRef]

192. Sanlorenzo, M.; Vujic, I.; Esteve-Puig, R.; Lai, K.; Vujic, M.; Lin, K.; Posch, C.; Dimon, M.; Moy, A.; Zekhtser, M.; et al. The lincRNA MIRAT binds to IQGAP1 and modulates the MAPK pathway in NRAS mutant melanoma. Sci. Rep. 2018, 8, 10902. [CrossRef] [PubMed]

193. Wu, K.; Wang, Q.; Liu, Y.L.; Xiang, Z.; Wang, Q.Q.; Yin, L.; Liu, S.L. LncRNA POU3F3 Contributes to Dacarbazine Resistance of Human Melanoma Through the MiR-650/MGMT Axis. Front. Oncol. 2021, 11, 643613. [CrossRef] [PubMed]

194. Pan, B.; Lin, X.; Zhang, L.; Hong, W.; Zhang, Y. Long noncoding RNA X-inactive specific transcript promotes malignant melanoma progression and oxaliplatin resistance. Melanoma Res. 2019, 29, 254-262. [CrossRef] [PubMed]

195. An, L.F.; Huang, J.W.; Han, X.; Wang, J. Downregulation of lncRNA H19 sensitizes melanoma cells to cisplatin by regulating the miR-18b/IGF1 axis. Anticancer Drugs 2020, 31, 473-482. [CrossRef]

196. Wu, L.; Li, K.; Lin, W.; Liu, J.; Qi, Q.; Shen, G.; Chen, W.; He, W. Long noncoding RNA LINC01291 promotes the aggressive properties of melanoma by functioning as a competing endogenous RNA for microRNA-625-5p and subsequently increasing IGF-1R expression. Cancer Gene Ther. 2021, 1-17. [CrossRef]

197. Sole, C.; Arnaiz, E.; Manterola, L.; Otaegui, D.; Lawrie, C.H. The circulating transcriptome as a source of cancer liquid biopsy biomarkers. Semin Cancer Biol. 2019, 58, 100-108. [CrossRef]

198. Li, Q.; Shao, Y.; Zhang, X.; Zheng, T.; Miao, M.; Qin, L.; Wang, B.; Ye, G.; Xiao, B.; Guo, J. Plasma long noncoding RNA protected by exosomes as a potential stable biomarker for gastric cancer. Tumour Biol. 2015, 36, 2007-2012. [CrossRef]

199. Xiao, W.; Yin, A. LINC0638 lncRNA is involved in the local recurrence of melanoma following surgical resection. Oncol. Lett. 2019, 18, 101-108. [CrossRef]

200. Chen, X.; Gao, G.; Liu, S.; Yu, L.; Yan, D.; Yao, X.; Sun, W.; Han, D.; Dong, H. Long Noncoding RNA PVT1 as a Novel Diagnostic Biomarker and Therapeutic Target for Melanoma. BioMed Res. Int. 2017, 2017, 7038579. [CrossRef]

201. Kolenda, T.; Rutkowski, P.; Michalak, M.; Kozak, K.; Guglas, K.; Rys, M.; Galus, L.; Wozniak, S.; Lugowska, I.; Gos, A.; et al Plasma lncRNA expression profile as a prognostic tool in BRAF-mutant metastatic melanoma patients treated with BRAF inhibitor. Oncotarget 2019, 10, 3879-3893. [CrossRef]

202. Ling, H.; Fabbri, M.; Calin, G.A. MicroRNAs and oTher. non-coding RNAs as targets for anticancer drug development. Nat. Rev. Drug Discov. 2013, 12, 847-865. [CrossRef] [PubMed]

203. Winkle, M.; El-Daly, S.M.; Fabbri, M.; Calin, G.A. Noncoding RNA therapeutics—challenges and potential solutions. Nat. Rev. Drug Discov. 2021, 20, 629-651. [CrossRef] [PubMed]

204. Arun, G.; Diermeier, S.D.; Spector, D.L. Therapeutic Targeting of Long Non-Coding RNAs in Cancer. Trends Mol. Med. 2018, 24, 257-277. [CrossRef]

205. Pendergraff, H.M.; Krishnamurthy, P.M.; Debacker, A.J.; Moazami, M.P.; Sharma, V.K.; Niitsoo, L.; Yu, Y.; Tan, Y.N.; Haitchi, H.M.; Watts, J.K. Locked Nucleic Acid Gapmers and Conjugates Potently Silence ADAM33, an Asthma-Associated Metalloprotease with Nuclear-Localized mRNA. Mol. Ther. Nucleic Acids 2017, 8, 158-168. [CrossRef] [PubMed]

206. Shi, Y.; Parag, S.; Patel, R.; Lui, A.; Murr, M.; Cai, J.; Patel, N.A. Stabilization of lncRNA GAS5 by a Small Molecule and Its Implications in Diabetic Adipocytes. Cell Chem. Biol. 2019, 26, 319-330.e6. [CrossRef]

207. Donlic, A.; Morgan, B.S.; Xu, J.L.; Liu, A.; Roble, C., Jr.; Hargrove, A.E. Discovery of Small Molecule Ligands for MALAT1 by Tuning an RNA-Binding Scaffold. Angew. Chem. Int. Ed. Engl. 2018, 57, 13242-13247. [CrossRef]

208. Abulwerdi, F.A.; Xu, W.; Ageeli, A.A.; Yonkunas, M.J.; Arun, G.; Nam, H.; Schneekloth, J.S., Jr.; Dayie, T.K.; Spector, D.; Baird, N.; et al. Selective Small-Molecule Targeting of a Triple Helix Encoded by the Long Noncoding RNA, MALAT1. ACS Chem. Biol. 2019, 14, 223-235. [CrossRef]

209. Dimitrova, N.; Zamudio, J.R.; Jong, R.M.; Soukup, D.; Resnick, R.; Sarma, K.; Ward, A.J.; Raj, A.; Lee, J.T.; Sharp, P.A.; et al LincRNA-p21 activates p21 in cis to promote Polycomb target gene expression and to enforce the G1/S checkpoint. Mol. Cell 2014, 54, 777-790. [CrossRef]

210. Amirinejad, R.; Rezaei, M.; Shirvani-Farsani, Z. An update on long intergenic noncoding RNA p21: A regulatory molecule with various significant functions in cancer. Cell Biosci. 2020, 10, 82. [CrossRef] 
211. Pawar, G.; Parayath, N.N.; Sharma, A.A.; Coito, C.; Khorkova, O.; Hsiao, J.; Curry, W.T.; Amiji, M.M.; Bleier, B.S. Endonasal CNS Delivery System for Blood-Brain Barrier Impermeant Therapeutic Oligonucleotides Using Heterotopic Mucosal Engrafting. Front. Pharmacol. 2021, 12, 660841. [CrossRef]

212. Modarresi, F.; Faghihi, M.A.; Lopez-Toledano, M.A.; Fatemi, R.P.; Magistri, M.; Brothers, S.P.; van der Brug, M.P.; Wahlestedt, C. Inhibition of natural antisense transcripts in vivo results in gene-specific transcriptional upregulation. Nat. Biotechnol. 2012, 30, 453-459. [CrossRef] [PubMed]

213. Yu, Q.; Qiu, Y.; Wang, X.; Tang, J.; Liu, Y.; Mei, L.; Li, M.; Yang, M.; Tang, L.; Gao, H.; et al. Efficient siRNA transfer to knockdown a placenta specific lncRNA using RGD-modified nano-liposome: A new preeclampsia-like mouse model. Int. J. Pharm. 2018, 546, 115-124. [CrossRef] [PubMed]

214. Zhang, Z.C.; Tang, C.; Dong, Y.; Zhang, J.; Yuan, T.; Li, X.L. Targeting LncRNA-MALAT1 suppresses the progression of osteosarcoma by altering the expression and localization of beta-catenin. J. Cancer 2018, 9, 71-80. [CrossRef]

215. Chang, L.; Wang, G.; Jia, T.; Zhang, L.; Li, Y.; Han, Y.; Zhang, K.; Lin, G.; Zhang, R.; Li, J.; et al. Armored long non-coding RNA MEG3 targeting EGFR based on recombinant MS2 bacteriophage virus-like particles against hepatocellular carcinoma. Oncotarget 2016, 7, 23988-24004. [CrossRef] [PubMed]

216. Vaidya, A.M.; Sun, Z.; Ayat, N.; Schilb, A.; Liu, X.; Jiang, H.; Sun, D.; Scheidt, J.; Qian, V.; He, S.; et al. Systemic Delivery of Tumor-Targeting siRNA Nanoparticles against an Oncogenic LncRNA Facilitates Effective Triple-Negative Breast Cancer Therapy. Bioconjug. Chem. 2019, 30, 907-919. [CrossRef] [PubMed]

217. Gong, N.; Teng, X.; Li, J.; Liang, X.J. Antisense Oligonucleotide-Conjugated Nanostructure-Targeting lncRNA MALAT1 Inhibits Cancer Metastasis. ACS Appl. Mater. Interfaces 2019, 11, 37-42. [CrossRef] [PubMed]

218. Pegtel, D.M.; Gould, S.J. Exosomes. Annu. Rev. Biochem. 2019, 88, 487-514. [CrossRef] [PubMed]

219. Carlevaro-Fita, J.; Lanzos, A.; Feuerbach, L.; Hong, C.; Mas-Ponte, D.; Pedersen, J.S.; Drivers, P.; Functional Interpretation, G.; Johnson, R.; Consortium, P. Cancer LncRNA Census reveals evidence for deep functional conservation of long noncoding RNAs in tumorigenesis. Commun. Biol. 2020, 3, 56. [CrossRef]

220. Kim, J.; Piao, H.L.; Kim, B.J.; Yao, F.; Han, Z.; Wang, Y.; Xiao, Z.; Siverly, A.N.; Lawhon, S.E.; Ton, B.N.; et al. Long noncoding RNA MALAT1 suppresses breast cancer metastasis. Nat. Genet. 2018, 50, 1705-1715. [CrossRef]

221. Gutschner, T.; Hammerle, M.; Eissmann, M.; Hsu, J.; Kim, Y.; Hung, G.; Revenko, A.; Arun, G.; Stentrup, M.; Gross, M.; et al. The noncoding RNA MALAT1 is a critical regulator of the metastasis phenotype of lung cancer cells. Cancer Res. 2013, 73, 1180-1189. [CrossRef] 